
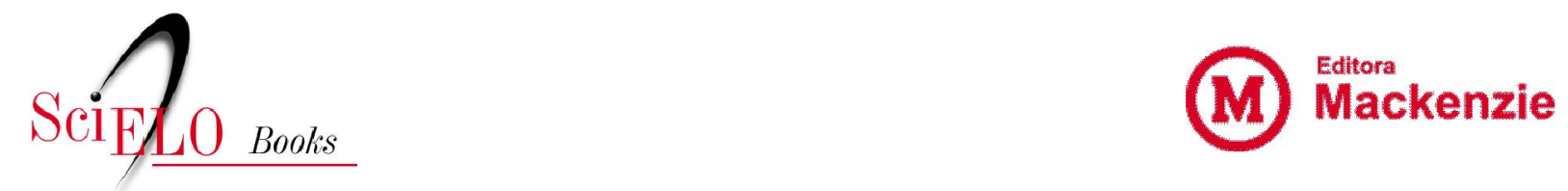

\author{
Competência em leitura \\ interface entre contextos psicossocial, familiar e escolar \\ Eva Cristina de Carvalho Souza Mendes \\ Decio Brunoni
}

SciELO Books / SciELO Livros / SciELO Libros

MENDES, ECCS., and BRUNONI, D. Competência em leitura: interface entre contextos psicossocial, familiar e escolar [online]. São Paulo: Editora Mackenzie, 2015. Saberes em tese collection, vol. 11, 84 p. ISBN: 978-85-8293-724-2. Available from: doi: 10.7476/9788582937242. Also available in ePUB from: http://books.scielo.org/id/g2v7w/epub/mendes-9788582937242.epub.

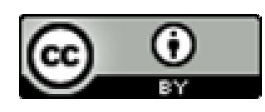

All the contents of this work, except where otherwise noted, is licensed under a Creative Commons Attribution $\underline{4.0 \text { International license. }}$

Todo o conteúdo deste trabalho, exceto quando houver ressalva, é publicado sob a licença Creative Commons Atribição 4.0.

Todo el contenido de esta obra, excepto donde se indique lo contrario, está bajo licencia de la licencia $\underline{\text { Creative }}$ Commons Reconocimento 4.0. 


\section{Competência em leitura: interface entre contextos psicossocial, familiar e escolar}




\section{压}

Coleção Saberes em Tese, 11

UNIVERSIDADE PRESBITERIANA MACKENZIE

Reitor: Benedito Guimarães Aguiar Neto

Vice-reitor: Marcel Mendes

PRÓ-REITORIA DE PESQUISA E PÓS-GRADUAÇÃO

Pró-reitora: Helena Bonito Pereira

EDITORA MACKENZIE

Conselho Editorial

Helena Bonito Pereira (Presidente)

José Francisco Siqueira Neto

Leila Figueiredo de Miranda

Luciano Silva

Maria Cristina Triguero Veloz Teixeira

Maria Lucia Marcondes Carvalho Vasconcelos

Moises Ari Zilber

Valter Luís Caldana Júnior

Wilson do Amaral Filho

\section{COLEÇÃO SABERES EM TESE}

Diretor: Benedito Guimarães Aguiar Neto 
Eva Cristina de Carvalho Souza Mendes Decio Brunoni

\section{Competência em leitura: interface entre contextos psicossocial, familiar e escolar}


(C) 2015 Eva Cristina de Carvalho Souza Mendes e Decio Brunoni

Todos os direitos reservados à Editora Mackenzie.

Nenhuma parte desta publicação poderá ser reproduzida por qualquer meio ou forma sem a prévia autorização da Editora Mackenzie.

Coordenadora de produção editorial: Joana Figueiredo

Produtora editorial: Jéssica Dametta

Capa e projeto gráfico: Alberto Mateus

Diagramação: Crayon Editorial

Preparação de texto: Luiza Delamare

Revisão: Hebe Ester Lucas

Dados Internacionais de Catalogação na Publicação (CIP)

(Câmara Brasileira do Livro, SP, Brasil)

Mendes, Eva Cristina de Carvalho Souza

Competência em leitura : interface entre contextos

psicossocial, familiar e escolar / Eva Cristina de Carvalho

Souza Mendes, Decio Brunoni. -- São Paulo : Editora

Mackenzie, 2015. -- (Coleção saberes em tese ; v. 11)

Bibliografia

ISBN: 978-85-8293-302-2

1. Competência 2. Escrita 3. Leitura - Avaliação (Ensino fundamental) 4. Leitura - Testes 5. Livros e leitura I. Brunoni, Decio. II. Título. III. Série.

Índice para catálogo sistemático:

1. Leitura : Teste de competência : Linguística 418.4

2. Prática de leitura : Linguística :

Teste de competência 418.4

\section{EDITORA MACKENZIE}

Rua da Consolação, 930

Edifício João Calvino, 7o andar

São Paulo - SP - CEP 01302-907

Tel.: (5511) 2114-8774

editora@mackenzie.br I livraria@mackenzie.br

www.mackenzie.br/editora.html 


\section{Sumário}

SOBRE OS AUTORES ................ 7 APRESENTAÇÃO

Alessandra Gotuzo Seabra . . . . . . . . . . . . . 9 INTRODUÇÃO . . . . . . . . . . . . . . 11

CAPÍTULO 1

Competência em leitura: construção do enfoque . . . . . . . 15 CAPÍTULO 2

Recursos e suporte do ambiente familiar

e aspectos cognitivos: contribuições na aquisição

da competência em leitura . . . . . . . . . . 21

CAPÍTULO 3

Contexto escolar: sistema de avaliação e competência em leitura . . . . . . . . . . . . . . . . 45

REFERENCIAS . . . . . . . . . . . . 75 ÍNDICE .................... . . . . . . 


\section{Sobre os autores}

Eva Cristina de Carvalho Souza Mendes é doutora em Distúrbios do Desenvolvimento pela Universidade Presbiteriana Mackenzie (UPM) e mestre em Educação pela Universidade Católica de Santos (Unisantos). Foi professora e diretora de escola e atuou na Supervisão de Ensino da Prefeitura Municipal de Santos. Atualmente, é coordenadora local e docente do curso de Pedagogia da Universidade Paulista, campus Santos, e presidente do Conselho Municipal de Educação de Santos. Tem experiência em educação, atuando principalmente nas seguintes áreas: Educação Básica, Educação Profissional, Educação a Distância, Processo Ensino-aprendizagem, Orientação Educacional, Administração Escolar, Supervisão Escolar, Psicopedagogia e Pedagogia.

Decio Brunoni é médico especialista em Genética Médica e tem mestrado, doutorado e livre-docência em Genética Humana e Médica. É sócio-fundador e honorário da Sociedade Brasileira de Genética Médica e professor aposentado da Universidade Federal de São Paulo (Unifesp), onde foi criador e coordenador do Centro de Genética Médica e do Programa de Residência em Genética Médica. Atualmente, é Professor Titular do Programa de Pós-Graduação em Distúrbios do Desenvolvimento da Universidade Presbiteriana Mackenzie (UPM). 


\section{Apresentação}

Em Competência em leitura: interface entre contextos psicossocial, familiar e escolar, os autores buscam mapear a competência em leitura de alunos de $3^{\circ}$ ano do Ensino Fundamental da cidade de Santos (SP), bem como compreender, de forma abrangente, as variáveis que prediziam tal competência. Para isso, foi feita uma ampla revisão do processo de aquisição de leitura, dos instrumentos disponíveis para avaliação das etapas envolvidas e também das avaliações educacionais formais de amplo alcance, como a Provinha Brasil.

Destacamos a relevância da pesquisa ao analisar, simultaneamente, diversos fatores que têm se mostrado importantes para o desempenho escolar, incluindo:

» os aspectos cognitivos (como inteligência, compreensão auditiva, nomeação rápida e aspectos básicos da leitura, como reconhecimento de palavras); e

os aspectos psicossocioambientais (como recursos e suporte do ambiente familiar, nível econômico e educacional dos pais).

O formato final do livro torna a leitura prazerosa e fluida. Acreditamos que os leitores se beneficiarão dos achados aqui relatados e das discussões levantadas. 
Esse enfoque certamente contribuirá para uma compreensão mais aprofundada dos processos envolvidos na aquisição da leitura em alunos brasileiros, abrindo portas para intervenções mais eficazes que possam colaborar com o fomento dessa competência tão relevante para as nossas crianças.

Alessandra Gotuzo Seabra em março de 2015 


\section{Introdução}

Os resultados insatisfatórios do desempenho escolar e da aprendizagem da leitura, além das questões sobre o nível de aprendizado das crianças e possíveis fatores intervenientes, têm trazido inquietação a pesquisadores de várias áreas do conhecimento.

O desempenho dos estudantes brasileiros, aferido por meio dos exames de avaliação do Ministério da Educação (MEC), demonstra que a aprendizagem dos alunos ainda está abaixo dos padrões adequados. Esse baixo desempenho possui várias causas internas e externas à escola (DOURADO, 2005).

O desempenho para leitura exige que os alunos escrevam com correspondência sonora alfabética e produzam textos com algumas características da linguagem escrita, de acordo com o gênero proposto. Além disso, devem ser capazes de localizar, na leitura, informações explícitas contidas no texto informativo. Essas seriam as competências esperadas para alunos na fase inicial de aquisição da leitura e da escrita, de acordo com o Instituto Nacional de Estudos e Pesquisas Educacionais Anísio Teixeira (Inep) (BRASIL, 2011).

Os indicadores em Língua Portuguesa apurados pela média total na Prova Brasil 2011, nos anos iniciais do Ensino Fundamental, refletem 190,6 pontos de um total de 350, o que indica que os avaliados estão no nível 3 de desempenho em leitura, conforme a escala de desempenho de Língua Portuguesa Ensino Fun- 
damental (BRASIL, 2011). De acordo com essa escala, no nível 3, os alunos localizam informações explícitas no texto, interpretam o tema abordado a partir da inferência, identificam o personagem principal e reconhecem elementos que compõem uma narrativa.

Ao final do Ensino Fundamental, espera-se que o aluno demonstre habilidades de leitura que envolvam: compreensão global de texto, avaliação e estabelecimento de relações entre textos e partes de textos mais longos e com vocabulário complexo, inferência de informações em diversos contextos e início da leitura com compreensão de textos da literatura clássica (BRASIL, 2011).

No estado de São Paulo, a Secretaria da Educação divulgou os resultados do Sistema de Avaliação de Rendimento Escolar do Estado de São Paulo (Saresp) de 2011 (SÃO PAULO, 2012), avaliação externa da Educação Básica em larga escala, aplicada a cada ano desde 1996. Os resultados indicaram que cerca de $71 \%$ das escolas da rede estadual apresentaram, na avaliação dos alunos de $3^{\circ}$ ano do Ensino Fundamental, bom desempenho para leitura, conforme critério do teste, qual seja, 53,5 de um total de 72 pontos. Já na avaliação dos alunos de $5^{\circ}$ ano do Ensino Fundamental, a média da Rede Estadual foi de 195 pontos em Língua Portuguesa, o que equivale ao nível básico de proficiência e domínio mínimo dos conteúdos, competências e habilidades necessários para interagir com a proposta curricular do ano subsequente.

O desenvolvimento da competência em leitura e escrita está relacionado ao bom desempenho da linguagem e da habilidade de estar, conscientemente, atento aos sons da fala (CAPOVILLA; CAPOVILLA, 2002; MORAIS, 1996).

Em uma reflexão sobre o desempenho em leitura, visto que essa atividade tem papel importante no ambiente escolar, cabe lembrar que muitos são os fatores intervenientes na aquisição da leitura que impactam o nível de aprendizado das crianças.

Este livro pretende apresentar como se dá o processo de aquisição da competência em leitura, bem como estabelecer uma rela- 
ção da leitura com os variados contextos psicossocioambientais, familiares e escolares.

A opção por estudar a competência em leitura de crianças do $3^{\circ}$ ano do Ensino Fundamental se justifica pelo empenho dos alunos, nos dois anos anteriores, na aprendizagem da leitura. Além disso, espera-se que esses educandos já leiam de maneira relativamente fluente, como previsto pelo MEC, no ano de 2012, com a instituição da Portaria $\mathrm{n}^{\mathrm{o}}$ 867, o Pacto Nacional pela Alfabetização na Idade Certa, o qual determina a alfabetização de crianças com até, no máximo, oito anos de idade, ao final do $3^{\circ}$ ano do Ensino Fundamental (BRASIL, 2012c). Para tanto, as ações do Pacto compreendem os seguintes eixos: 1. formação continuada de professores alfabetizadores; 2. materiais didáticos, literatura e tecnologias educacionais; 3. avaliação e gestão; e 4. controle e mobilização social.

Mais recentemente, o Ministério da Educação, por meio da Secretaria de Educação Básica (BRASIL, 2013), propôs, entre outros objetivos da formação básica, definidos para a Educação Infantil e prolongando-os para o Ensino Fundamental,

[...] o desenvolvimento da capacidade de aprender, tendo como meios básicos o pleno domínio da leitura, da escrita e do cálculo [...], bem como [...] foco central na alfabetização, ao longo dos três primeiros anos [...].

No que se refere à conquista da competência em leitura e escrita, o Ministério da Educação (BRASIL, 2004) propõe que, além de inserir os alunos em um ambiente com acesso aos diversos usos da leitura e da escrita,

[...] é necessário, além disso, um trabalho sistemático, centrado tanto nos aspectos funcionais e textuais, quanto no aprendizado dos aspectos gráficos da linguagem escrita e daqueles referentes ao sistema alfabético de representação [...]. 
Cabe ressaltar a complexidade que cerca o processo de alfabetização infantil, considerando que, mesmo antes de iniciar a escolarização, a criança está inserida em um ambiente que faz uso do sistema de leitura e escrita, ao ouvir uma história, identificar placas, brincar com jogos de rima, aliteração, entre outros (SOARES, 2011).

Com base nos contextos em que a leitura está inserida, a hipótese formulada é que os resultados de uma avaliação em grande escala, como a Provinha Brasil e os testes de leitura, podem estar correlacionados com variadas situações.

À luz do exposto sobre o tema deste livro, apresentam-se as partes que o compõem.

No Capítulo 1, são tecidas considerações acerca da competência em leitura em uma abordagem cognitiva, tendo como suporte teórico: Barreira e Maluf (2003), Capovilla e Capovilla (2000), Salles e Parente (2002a, 2002b), Alégria, Leybaert e Mousty (1997), entre outros.

No Capítulo 2, são tratados os contextos psicossocioambientais e familiares, os recursos de suporte do ambiente familiar e a competência em leitura à luz dos estudos de Marturano (2006), Trivellato-Ferreira e Marturano (2008), Ferreira e Barrera (2010), Soares e Andrade (2006), Santos e Graminha (2005), Enricone e Salles (2011), Piccolo et al. (2012), Cardoso-Martins e Pennington (2001), Bicalho e Alves (2010), Silva et al. (2012) e Rosal (2014).

Por fim, no Capítulo 3, é enfocado o sistema de avaliação no desempenho de leitura e escrita, mais especificamente a Provinha Brasil - Leitura e testes psicométricos de medição da competência em leitura. São sugeridas também possibilidades para discussão da temática em análise.

Desejamos que sua leitura abra espaço para novas conquistas no que diz respeito ao conhecimento e às práticas realizáveis para o desenvolvimento da competência leitora nos mais variados contextos. 


\section{Competência em leitura: construção do enfoque}

\section{Como se dá a leitura?}

A aquisição da leitura é fundamental para o progresso de uma cultura. A aprendizagem da leitura tem como base o reconhecimento de que os símbolos (letras/grafemas) representam unidades, que, por sua vez, formam palavras no sistema de escrita. Em seguida, é possível reconhecer que cada unidade escrita corresponde a uma unidade sonora (fonema). Daí a importância de compreender e de se apropriar do sistema de escrita.

O sistema de escrita da língua portuguesa é alfabético. Trata-se de um código com correspondências unívocas, porém com certas ambiguidades (MATTOSO CÂMARA, 1985). No caso da leitura em língua portuguesa, há correspondências e relações entre grafemas (letras) e fonemas (sons).

Isso aponta a necessidade de haver, nas palavras escritas, uma sequência de letras (grafemas) que se repetem e são representadas por sons da fala (fonemas). Para compreender o princípio alfabético, três fatores são necessários: a consciência da possibilidade de segmentação da língua falada em unidades distintas, a consciência de que tais unidades repetem-se em diferentes palavras faladas e o conhecimento da correspondência grafofonêmica (GUIMARÃES, 2003). 
Assim, o processo de leitura depende da decodificação de palavras, da fluência e da compreensão da escrita. Segundo Barbante, Amaro Jr. e Costa (2011, p. 61),

[...] neste processo, ocorre inicialmente a análise visual, dependente, portanto, deste sistema sensorial e da atenção seguida do processamento linguístico da leitura, para a associação grafema-fonema e leitura global da palavra.

Segundo Barreira e Maluf (2003, p. 493),

[...] o grande contingente de alunos que apresenta dificuldades para se alfabetizar tem levado muitos autores a defender a importância da sistematização de atividades pedagógicas visando desenvolver os diferentes níveis de consciência fonológica no início do processo de alfabetização, de modo a facilitar a aquisição da linguagem escrita.

Diante disso, é necessário entender que o sistema de leitura é construído progressivamente com base na capacidade de transformar letras (grafemas) em sons (fonemas), bem como na habilidade de refletir sobre a linguagem (habilidades metalinguísticas, tais como a consciência fonológica e a consciência sintática) até chegar à compreensão textual.

\section{Consciência fonológica e consciência sintática}

A consciência fonológica desenvolve-se à medida que a criança torna-se consciente de palavras, sílabas e fonemas como unidades identificáveis (CAPOVILLA; CAPOVILLA, 2000). Assim, a consciência fonológica é a capacidade de raciocinar sobre os sons da língua e de manipular os sons isolados da linguagem falada como menor unidade sonora, abrangendo a capacidade de reflexão e de operação de rimas, aliteração, sílabas e fonemas (contar, segmen- 
tar, unir, adicionar, suprimir, substituir) (BARBANTE; AMARO JR.; COSTA, 2011; GERMANO; PINHEIRO; CUNHA, 2010).

A consciência sintática é a reflexão sobre a estrutura da língua. A sintaxe está diretamente relacionada ao caráter articulatório da linguagem humana (BARREIRA; MALUF, 2003). Também é um fator importante para a aquisição da linguagem escrita, pois possibilita ao leitor ler palavras que ele não consegue decodificar por algum tipo de dificuldade, seja por um problema com a própria palavra (irregularidades grafofonêmicas), seja por uma dificuldade pessoal em decodificação. A consciência sintática é relevante para a compreensão de frases e textos (CAPOVILLA; CAPOVILLA; SOARES, 2004).

Os resultados encontrados por Capovilla, Capovilla e Soares (2004) em pesquisa realizada com 204 sujeitos de $1^{\underline{a}}$ a $4^{4^{\underline{a}}}$ séries do Ensino Fundamental (atualmente do $2^{\underline{o}}$ ao $5^{-}$ano), que avaliou a importância de habilidades metalinguísticas (consciência fonológica e sintática para aquisição de leitura e escrita), mostraram-se significativos para as séries estudadas e no que diz respeito à consciência fonológica, à consciência sintática, à competência de leitura, à escrita sob ditado e ao vocabulário apontando sua correlação.

\section{Leitura: processamento da informação de dupla rota}

À luz da abordagem cognitiva, a leitura e a escrita são atividades complexas, compostas por múltiplos processos interdependentes, geralmente representados por meio de modelos de processamento da informação (SALLES; PARENTE, 2002a).

Um dos modelos que têm recebido atenção da comunidade científica é o de leitura e de escrita de dupla rota, no qual ocorrem os processamentos fonológico e lexical (ELLIS; YOUNG, 1988). De acordo com esse modelo, a leitura pode ocorrer por meio de um processo visual direto, chamado rota lexical, no qual as representações de palavras frequentes e familiares são armazenadas em um 
léxico de entrada visual, ou seja, o sujeito possui uma representação ortográfica de uma palavra que dá acesso ao seu léxico interno, porque há o reconhecimento pelo emparelhamento da palavra escrita com sua representação ortográfica. Já a rota fonológica consiste na conversão grafema-fonema, que transforma as letras ou grupo de letras em seus correspondentes fonológicos (ALÉGRIA; LEYBAERT; MOUSTY, 1997; SALLES; PARENTE, 2002b).

Nesse modelo, a leitura é uma habilidade complexa que envolve a capacidade de refletir sobre a estrutura fonológica da linguagem oral, com a consciência de que a fala pode ser segmentada e de que existe a habilidade de discriminar e manipular tais segmentos (CAPOVILLA; CAPOVILLA, 2000; MORAIS et al., 1986), de modo que o processo vai da informação visual ao som (decodificação) para chegar à compreensão (JOSHI; AARON, 2000).

Dessa forma, para que a criança identifique uma palavra escrita, há que relacionar a representação gráfica da palavra com a unidade correspondente no léxico interno, e esse reconhecimento ocorre pela associação da palavra escrita à sua representação ortográfica (rota lexical) e também pela associação da representação fonológica da palavra escrita, que transforma as letras ou o grupo de letras em seus correspondentes fonológicos (rota fonológica) (ALÉGRIA; LEYBAERT; MOUSTY, 1997).

Segundo Frith (1985 apud CAPOVILLA; CAPOVILLA, 2000), existem três estratégias básicas para lidar com a palavra escrita:

1 logográfica, que implica o reconhecimento das palavras por meio do desenho como um todo;

2 fonológica, que prevê a análise das palavras em seus componentes grafofonêmicos, ou seja, a codificação e decodificação da palavra escrita;

3 lexical, que se refere à construção de unidades de reconhecimento nos níveis lexical e morfêmico, isto é, partes das palavras podem ser identificadas diretamente, sem conversão fonológica. 
Verifica-se, portanto, que a leitura será mais fluente quando a criança for capaz de processar melhor as informações fonológicas e as representações ortográficas.

Um fator que pode facilitar a aprendizagem da leitura é a nomeação automática rápida (NAR) de símbolos/estímulos visuais. Pesquisadores como Santos (2007), Cardoso-Martins e Pennington (2001), Bicalho e Alves (2010), Silva et al. (2012) e Rosal (2014) têm apresentado estudos relevantes sobre isso. Esse processo considera que, ao nomear uma série de estímulos visuais familiares - letras, números, cores e figuras - o mais rapidamente possível, a criança poderá exercitar uma leitura textual fluente. Afinal, "quanto maior a habilidade de reconhecer palavras escritas rápida e acuradamente, maior a quantidade de recursos intelectuais disponíveis à compreensão" (SILVA et al., 2012, p. 356).

Além do reconhecimento da palavra, a leitura supõe a compreensão do texto lido, processo cognitivo igualmente complexo. O reconhecimento das palavras é condição necessária, porém insuficiente para a compreensão de um texto (ALÉGRIA; LEYBAERT; MOUSTY, 1997), o que requer capacidades cognitivas, como inferências (BRAIBANT, 1997).

\section{Compreensão do texto}

No que se refere à compreensão do texto, Kintsch e Van Dijk (1978) distinguem três níveis na representação do discurso:

1 a estrutura de superfície (palavras e sintagmas utilizados no texto), na qual são preservadas as palavras exatas e a sintaxe das orações;

2 o conteúdo semântico local (microestrutura), que abrange detalhes menos relevantes, corresponde às representações semânticas (proposições) estabelecidas para sentenças ou sequências de sentenças e é responsável pela organização se- 
quencial e pela coerência do discurso, e o conteúdo semântico global (macroestrutura), que abarca as ideias essenciais do texto, refere-se ao significado global do discurso, implicando as relações explícitas e implícitas entre suas proposições; e

3 o modelo de situação, que é uma representação mental daquilo que é explicitamente mencionado ou inferencialmente sugerido no texto.

Para tanto, a compreensão é um processo que permite elaborar a macroestrutura do texto a partir de sua microestrutura, possibilitando ao leitor tecer inferências relacionadas.

Desse modo, para que a leitura se realize, é necessária a inter-relação de vários processos cognitivos.

A compreensão de texto será bem-sucedida quando inferências, habilidades linguísticas, memória, conhecimento de mundo estiverem articulados nos processos cognitivos de alto nível em uma construção de representação macroestrutural do texto (SILVA; FUSCO; CUNHA, 2010). 


\section{Recursos e suporte do ambiente familiar e aspectos cognitivos: contribuições na aquisição da competência em leitura}

\section{Contexto psicossocioambiental: componentes}

Muitos são os fatores que podem interferir no desempenho de tarefas de leitura e escrita entre alunos do Ensino Fundamental, em especial nos das séries iniciais. Como exemplo, é possível citar o apoio da família, a adaptação ao ambiente escolar, a atuação do educador como facilitador, o repertório psicomotor, a aquisição da linguagem oral, o desenvolvimento das habilidades de reconhecimento de palavras, a competência em leitura e escrita, os programas eficazes de alfabetização, além de crenças e atitudes de alguns educadores no que se refere à linguagem falada e escrita e as relações entre elas, como apontado por Santos, Anderle e Rosa Neto (2010), Barreira e Maluf (2003) e Capovilla e Capovilla (2000).

A aprendizagem da leitura, as questões sobre o nível de aprendizado das crianças e possíveis fatores intervenientes têm 
trazido inquietação a pesquisadores de várias áreas do conhecimento, como educação, psicologia e saúde (TRIVELLATO-FERREIRA; MARTURANO, 2008; FERREIRA; BARRERA, 2010; SOARES; ANDRADE, 2006; SOARES; COLLARES, 2006; MURILLO; MARTINEZ-GARRIDO, 2012; NASCIMENTO, 2012; SALLES; PARENTE, 2007; CAPOVILLA; CAPOVILLA, 2006; SEABRA; CAPOVILLA, 2010).

Papalia, Olds e Feldman (2009, p. 340) afirmam que

[...] a experiência escolar das crianças afeta e é afetada por todos os aspectos do desenvolvimento - cognitivo, físico, emocional e social. Além das características próprias da criança, cada nível do contexto das suas vidas, desde a família próxima aos acontecimentos na sala de aula e às mensagens que recebem da sua cultura mais alargada influenciam a realização escolar.

Tomando por base o modelo de leitura de múltiplos componentes, definidos como sistemas de processamento de informação elementar que operam em representações internas de objetos e símbolos, apresentado por Aaron et al. (2008), o desenvolvimento e o desempenho da habilidade de leitura teriam a influência de:

1 variáveis cognitivas, que dizem respeito ao reconhecimento de palavras e à compreensão, entre outras habilidades relacionadas à leitura;

2 variáveis ambientais, que incluem aspectos do ambiente doméstico e cultural, engajamento dos pais nas atividades escolares e o ambiente de sala de aula;

3 variáveis psicológicas, que podem incluir a motivação e o interesse, os estilos de aprendizagem e as diferenças de expectativa de professores e de gênero. 
De acordo com os autores, a importância dessas variáveis tem sido reconhecida por educadores por um longo tempo e tem sido também empiricamente documentada (AARON et al., 2008).

$\mathrm{Na}$ abordagem ecocultural de desenvolvimento, é possível identificar tanto os fatores de risco quanto os de proteção como contribuintes para o desenvolvimento educacional e pessoal/social de crianças, visto que dados agregados são preditores mais válidos que indicadores individuais (KEOGH; WEISNER, 1993).

À luz dessa abordagem, cada contexto é entendido como um dos componentes do processo de desenvolvimento e de conquistas da criança, visto que o contexto ecocultural também influencia expectativas e exigências das competências das crianças e de suas práticas por meio da condução dessa competência, bem como proporciona formação de percepções e respostas para as características da criança.

Ainda segundo a abordagem ecocultural de desenvolvimento, podem ser consideradas variáveis para indicadores de risco e de proteção as que incluem os mais variados contextos:

1 estado econômico, étnico e outros demográficos;

2 dados da criança relacionados a condição de risco, nível intelectual e de desenvolvimento, estado educacional, idioma de casa etc.;

3 dados da família relacionados a configuração, estabilidade da localização, emprego dos pais etc.;

4 medidas detalhadas de problemas e competências educacionais, sociais, emocionais e de comportamento da criança; sua história médica, número de hospitalizações etc.;

5 acomodações da família, como carga de trabalho dos pais, suporte familiar, disponibilidade e uso de recursos (KEOGH; WEISNER, 1993).

Há autores que têm elencado alguns desses contextos, que parecem influenciar o processo de aprendizagem escolar 
(MARTURANO, 1999; TRIVELLATO-FERREIRA; MARTURANO, 2008; FERREIRA; BARRERA, 2010; SOARES; ANDRADE, 2006; SANTOS; GRAMINHA, 2005; ENRICONE; SALLES, 2011; PICCOLO et al., 2012).

\section{Contexto familiar}

Estudos referentes ao contexto familiar e suas relações com o rendimento acadêmico, bem como de leitura, não são recentes.

$\mathrm{O}$ interesse em estudar o contexto familiar deve-se ao fato de que, durante o percurso de vida, especialmente na infância, os principais cuidados e estímulos necessários ao desenvolvimento infantil são oferecidos no seio familiar.

Nesses estudos estão incluídos o nível socioeconômico (renda familiar e classe social) e a escolaridade dos pais (mãe e pai), como apontado por Bandeira et al. (2006a, 2006b), Soares e Alves (2013), Zhang et al. (2013), Santos e Graminha (2005), Piccolo et al. (2012), entre outros.

Dourado (2005) afirma que o nível de rendimento familiar é apontado pelo Instituto Brasileiro de Geografia e Estatística (IBGE) (2005) como um dos fatores que exercem forte interferência na escolarização. O mesmo estudo mostra que os alunos que obtiveram melhores rendimentos em processos avaliativos têm mães com nível maior de escolaridade.

Em seu estudo, Bandeira et al. (2006b) avaliaram 257 crianças, sendo 75 alunos de escola particular e o restante de escolas públicas e não encontraram diferenças entre alunos do $1^{\circ}$ ao $4^{\circ}$ ano do Ensino Fundamental em competência acadêmica. Verificaram que alunos de escolas particulares em média têm pontuação mais alta que alunos de escolas públicas em anos semelhantes e que meninas são avaliadas como mais competentes que meninos. Encontraram também correlação entre o nível socioeconômico e a competência acadêmica, assim como maior escolaridade dos pais e competência acadêmica. 
Zhang et al. (2013) analisaram as relações entre nível socioeconômico, processamento fonológico, vocabulário e leitura em 262 crianças chinesas entre quatro e nove anos de idade, de diversos níveis socioeconômicos. Os resultados demonstraram que o nível socioeconômico contribuiu para variações de habilidades fonológicas e de vocabulário das crianças, bem como ratificaram resultados de outros estudos.

Segundo Soares e Alves (2013), o nível socioeconômico é resultado da agregação de vários indicadores. O modelo apresentado pelos pesquisadores transforma as informações sobre o nível de escolaridade dos pais, a posse dos bens de consumo duráveis e a contratação de serviços domésticos em uma escala de desvios padrão em um quadro intervalar entre zero e 10 . O estudo mostrou que as escolas que tiveram o Índice de Desenvolvimento da Educação Básica (Ideb) calculado em 2011 são heterogêneas, em relação aos valores dos indicadores nível socioeconômico, dos alunos, dificuldade da gestão pedagógica e infraestrutura, conforme dados coletados pela Prova Brasil ou pelo Censo Escolar. Entretanto, evidencia que escolas que trabalham em condições mais favoráveis têm resultados melhores.

Enricone e Salles (2011) apontam a relação entre fatores psicossociais familiares e o desempenho em leitura e escrita, com base em um estudo comparativo realizado com 29 famílias de dois grupos de alunos de $2^{\underline{a}}$ série (atualmente $3^{\underline{o}}$ ano) do Ensino Fundamental, por meio de entrevista semiestruturada. Os dados indicam que, além dos fatores neurobiológicos e cognitivo-linguísticos, a investigação de fatores psicossociais, relativos ao letramento familiar e ao processo de escolarização, pode ser importante para compreender melhor a etiologia das dificuldades de leitura e escrita e qualificar a intervenção com essas crianças.

Nesse estudo, foram analisados, comparativamente, os fatores psicossociais familiares (recursos como: ambiente físico, materiais educacionais, acompanhamento familiar na aprendizagem e práti- 
cas educativas familiares) e a história prévia de desenvolvimento (linguagem, desenvolvimento motor, relações interpessoais, história de vida escolar) de dois grupos de crianças e sua possível relação com as habilidades de leitura e escrita. Os resultados revelaram que algumas variáveis psicossociais familiares estão relacionadas de forma mais significativa com o grupo de crianças com dificuldades de leitura/escrita. Além disso, houve associação significativa entre esse grupo de crianças e as variáveis: presença de transporte próprio na família (mais frequente no grupo competente), percepção dos familiares de que a criança teve dificuldades para aprender a ler, avaliação do familiar de que a criança tem dificuldade no desempenho da leitura, repetência escolar e história familiar de dificuldade na leitura (mais frequente no grupo com dificuldade).

Piccolo et al. (2012) investigaram, em um estudo longitudinal, a contribuição de fatores psicossociais para o desempenho em leitura de 59 crianças, sendo 29 meninos e 30 meninas, estudantes de $2^{\underline{a}}$ a $5^{\underline{a}}$ série (atualmente do $3^{-}$ao $6^{\underline{0}}$ ano) do Ensino Fundamental de escolas públicas. A renda familiar das crianças aos dois anos correlacionou-se positivamente com compreensão textual. Entretanto, apenas o número de familiares que residiam com a criança foi preditor do desempenho em leitura de palavras. A média geral de desempenho das crianças nas tarefas de leitura (de palavras e de texto) foi alta, considerando que a amostra variou entre $2^{\underline{a}}$ e $5^{\underline{a}}$ séries (atualmente $3^{\underline{o}}$ e $6^{\underline{o}}$ anos) e, nesse caso, havia outros fatores relacionados mais diretamente à criança competência social, autoestima, inteligência, capacidade para resolver problemas -, assim como as experiências compensadoras proporcionadas, por exemplo, por um ambiente escolar favorável podem ter funcionado como fatores protetores. Concluiu-se que o desempenho em leitura relaciona-se a fatores psicossociais, bem como observou-se que, de maneira sucinta, o desempenho em leitura parece estar ligado à renda familiar e à quantidade de pessoas que residem com a criança na amostra estudada, em que 
pese o estudo ter avaliado parcialmente apenas o aspecto socioeconômico e familiar relacionado ao desempenho em leitura.

Santos e Graminha (2005) desenvolveram um estudo com o objetivo de identificar diferentes características do contexto familiar que possam influenciar o rendimento acadêmico das crianças, incluindo: condições socioeconômico-educacionais, estrutura e relacionamento familiar, condições de gestação, participação da família na vida escolar das crianças, problemas de saúde física e/ou mental na família, práticas educativas, expectativas sobre o desenvolvimento da criança e recursos do ambiente familiar. Nesse estudo, os resultados apontam que, desde a sua concepção, crianças com baixo rendimento acadêmico estão inseridas em um contexto familiar mais adverso do que as que apresentam bom desempenho na escola. Ao mesmo tempo, as famílias do grupo de crianças com alto rendimento acadêmico oferecem mais materiais e estímulos para o seu desenvolvimento e as mães participam mais das reuniões escolares.

Em um estudo recente realizado por Mendes (2014), cujo objetivo era verificar a relação entre os resultados em testes de leitura, a pontuação obtida na Provinha Brasil - Leitura e as variáveis psicossocioambientais intervenientes na competência em leitura de crianças e comparar o desempenho naquela avaliação em função de características socioambientais da família, bem como recursos do ambiente familiar que contribuíssem para a aquisição da competência em leitura. Participaram do estudo 142 crianças, matriculadas no $3^{\circ}$ ano do Ensino Fundamental de quatro escolas da Rede Pública Municipal da cidade de Santos, com idades entre 8 e 11 anos (média = 8,62; desvio padrão $=0,58$ ), sendo 69 meninas (média $=8,62$; desvio padrão $=0,54$ ), correspondente a $48,6 \%$ da amostra, e 73 meninos (média $=8,62$; desvio padrão $=0,61)$, que corresponde a $51,4 \%$ da amostra. As escolas estão localizadas nas zonas Leste, Central, Noroeste e em morros da cidade de Santos. 
No que diz respeito à classe social, renda familiar e escolaridade das mães, são apresentados dados por meio de frequência e percentual.

Conforme descrito na Tabela 1 , em relação à classe social, no total de alunos pesquisados, de acordo com critérios estabelecidos pelo Critério de Classificação Econômica Brasil (CCEB) (ASSOCIAÇÃO BRASILEIRA DE EMPRESAS DE PESQUISA, 2012), 24,6\% pertencem à classe B, 54,2\%, à classe C, e 21,2\% pertencem à classe $\mathrm{D}$. A pontuação total obtida em questionário permitiu distribuir os indivíduos da seguinte forma: classe A (35 a 46 pontos), classe B (23 a 34 pontos), classe C (14 a 22 pontos), classe $\mathrm{D}$ ( 8 a 13 pontos) e classe $\mathrm{E}$ (0 a 7 pontos). O questionário era composto, em sua primeira parte, por itens como: profissão do pai e da mãe, posição da criança na família (filho mais velho, mais novo, intermediário ou filho único) e escolaridade do pai e da mãe. Na questão havia informações como: analfabeto, Ensino Fundamental I incompleto, Ensino Fundamental completo, Ensino Médio incompleto ou completo, Ensino Superior completo ou incompleto, bem como informações sobre a renda familiar e itens de conforto aos quais a família tem acesso.

TABELA 1 • DISTRIBUIÇÃO POR CLASSE SOCIAL DAS FAMÍLIAS DE UMA AMOSTRA DE ALUNOS DO 3 NO DO ENSINO FUNDAMENTAL POR ESCOLA NAS ZONAS LESTE, CENTRAL, NOROESTE E EM MORROS DO MUNICÍPIO DE SANTOS

\begin{tabular}{c|c|c|c|c|c|c} 
& $\begin{array}{c}(\mathbf{N}) \\
\text { ESCOLA Z } \\
\text { LESTE }\end{array}$ & $\begin{array}{c}(\mathbf{N}) \\
\text { ESCOLA Z } \\
\text { CENTRAL }\end{array}$ & $\begin{array}{c}(\mathbf{N}) \\
\text { ESCOLA Z } \\
\text { NOROESTE }\end{array}$ & $\begin{array}{c}\mathbf{( N )} \\
\text { ESCOLA Z } \\
\text { MORROS }\end{array}$ & $\begin{array}{c}(\mathbf{N}) \\
\text { TOTAL } \\
\text { ESCOLAS }\end{array}$ & $\begin{array}{c}\text { PERCENTUAL } \\
\text { TOTAL } \\
\text { ESCOLAS }\end{array}$ \\
\hline B & 10 & 3 & 9 & 13 & 35 & 24,6 \\
\hline C & 15 & 27 & 16 & 19 & 77 & 54,2 \\
\hline$D$ & 9 & 12 & 7 & 2 & 30 & 21,2 \\
\hline Total & 34 & 42 & 32 & 34 & 142 & 100,0
\end{tabular}


É possível observar que a maior parte das famílias distribuiu-se nas faixas C e B do nível socioeconômico, o que coincide com os resultados do Saresp 2011 na distribuição das famílias por classe social de crianças matriculadas no $3^{\circ}$ ano do Ensino Fundamental na rede pública do estado de São Paulo (2012).

Já a renda familiar foi avaliada diretamente pelo valor da remuneração mensal, a qual é possível caracterizar da seguinte maneira: $57,7 \%$ das famílias das crianças têm renda entre um e quatro salários mínimos, $16,2 \%$ têm renda familiar entre meio e um salário mínimo e apenas 4,9\% apresentam renda inferior a meio salário mínimo.

Segundo dados de condições de vida da Fundação Sistema Estadual de Análise de Dados (Seade), a renda domiciliar per capita no estado de São Paulo era de R \$ 853,49 e, no município de Santos, R\$ 1.364,92 (SÃO PAULO, 2010).

Em 2010, entre os domicílios brasileiros, 32\% concentravam rendimentos mensais de até meio salário mínimo per capita. No estado de São Paulo, a proporção era de 19\%. Na faixa intermediária de rendimentos, de meio a três salários mínimos per capita, situavam-se cerca de $58 \%$ dos domicílios no país e $66 \%$ dos paulistas. Nesse estudo, foi possível observar que, entre as escolas pesquisadas, $54 \%$ encontram-se na classe social C e, somando-se aos de classe social $\mathrm{D}$, totalizam $75 \%$ de pesquisados com renda média entre meio e três salários mínimos, valor inferior aos dados de condições de vida para o estado de São Paulo e o município de Santos (SÃO PAULO, 2010).

O município de Santos, que faz parte de uma região metropolitana com outros oito municípios, possui o melhor índice de desenvolvimento humano (IDH) em relação à renda (SANTOS, 2009).

Em relação à escolaridade das mães das crianças avaliadas, os resultados variaram entre analfabeta e com Ensino Fundamental I incompleto em $26,8 \%$, enquanto $7,1 \%$ têm nível superior 
completo. Pode-se observar que $60,6 \%$ das mães têm escolaridade entre Ensino Fundamental e Ensino Médio incompleto.

TABELA 2 - DISTRIBUIÇÃO DA ESCOLARIDADE DA MÃE DE UMA AMOSTRA DE ALUNOS DO 3ำ ANO DO ENSINO FUNDAMENTAL DE QUATRO ESCOLAS DAS ZONAS LESTE, CENTRAL, NOROESTE E EM MORROS DO MUNICÍPIO DE SANTOS

\begin{tabular}{c|c|c|c} 
& (N) & PERCENTUAL & CUMULATIVO \\
\hline Analfabeto & 2 & 1,4 & 1,4 \\
\hline $\begin{array}{c}\text { Ensino Fundamental I incompleto } \\
\text { Ensino Fundamental I completo/ } \\
\text { Ensino Fundamental II incompleto }\end{array}$ & 36 & 25,4 & 26,8 \\
\hline $\begin{array}{c}\text { Ensino Fundamental completo/ } \\
\text { Ensino Médio incompleto }\end{array}$ & 29 & 14,7 & 41,5 \\
\hline $\begin{array}{c}\text { Ensino Médio completo/ } \\
\text { Ensino Superior incompleto }\end{array}$ & 38 & 20,5 & 62,0 \\
\hline Ensino Superior completo & 10 & 7,1 & 88,7 \\
\hline Não informou & 6 & 4,2 & 100,0 \\
\hline Total & 142 & 100,0 &
\end{tabular}

FONTE: ELABORADA PELOS AUTORES.

Com relação às variáveis socioambientais - renda familiar, classificação econômica Brasil e escolaridade dos pais -, não houve correlação estatística significante com as variáveis de aprendizagem da leitura. Isso significa que as variáveis socioambientais não influíram nos resultados das variáveis de aprendizagem da leitura por não apoiarem os achados da literatura (BICALHO; ALVES, 2010). Vale ressaltar que as variáveis psicossocioambientais observadas no presente estudo dizem respeito à escolaridade dos pais, à renda familiar e à classe social.

Diante do exposto, é possível verificar que o contexto no qual o ser humano se desenvolve pode contribuir para a competência em leitura, com maior ou menor grau de vulnerabilidade aos riscos ou ao sucesso no processo de aprendizagem. 


\section{Recursos e suporte do ambiente familiar da criança e competência em leitura}

O ambiente no qual a criança está inserida pode contribuir para o seu pleno desenvolvimento. O contexto familiar tem sido apontado como um preditor do desempenho escolar infantil. Sabe-se que a família pode participar de maneira efetiva na formação do sujeito, o que pode contribuir para a motivação e o bom desempenho escolar. Além disso, o suporte ao desenvolvimento da criança pode refletir a disponibilidade e o envolvimento dos pais e familiares na sua vida acadêmica.

Segundo Marturano (1999), entre os fatores psicossociais, a influência do ambiente familiar no aprendizado escolar é amplamente reconhecida. Seus resultados denotam que a disponibilidade de materiais educacionais, o envolvimento dos pais no processo de desenvolvimento dos filhos, a interação entre eles e o uso da linguagem no lar, além do clima emocional e das práticas educativas utilizadas pela família, podem influenciar os processos de aprendizagem escolar das crianças.

Pires (2011) aponta que são considerados fatores psicossociais de risco: a ausência de relações parentais estáveis, a falta de apoio no contexto social em que vivem, transtornos econômicos, sociais ou pessoais, falta de cuidados maternos na infância, agressividade vigente nos grandes centros urbanos e desemprego. Ainda de acordo com o autor, os fatores psicossociais são reconhecidos como fatores de risco por causarem desordens comportamentais em crianças (PIRES, 2011).

O estudo de Trivellato-Ferreira e Marturano (2008) teve como objetivo verificar se o tempo de exposição à Educação Infantil estaria associado a indicadores de desempenho, competência interpessoal e percepção de estresse em alunos da $2^{\underline{a}}$ série do Ensino Fundamental (atualmente $3^{\underline{0}}$ ano). Como resultado, os autores apontaram que as avaliações de desempenho acadêmico foram favoráveis às crianças com EI, assim como suporte fami- 
liar e recursos da criança ao iniciar a transição. Essa pesquisa foi realizada em duas escolas públicas municipais e envolveu a participação de 70 crianças de ambos os gêneros e com idades entre 6 e 8 anos, além das mães e professoras. Nos resultados de regressão para cada indicador de competência no final do ano letivo, concluíram que o modelo final preditivo de desempenho escolar explica $43 \%$ da variância nos resultados do Teste de Desempenho Escolar e inclui recursos do ambiente familiar e práticas parentais positivas.

O objetivo da pesquisa realizada por Ferreira e Barrera (2010) foi analisar as relações entre ambiente familiar e desempenho escolar na Educação Infantil e, com base na análise dos dados, foi possível perceber que a maioria dos participantes apresentou desempenho médio. Os autores demonstraram associação positiva entre desempenho escolar e recursos do ambiente familiar. Esse resultado sugere que o desempenho escolar do aluno é influenciado por recursos do ambiente familiar no que se refere à disponibilidade de brinquedos e objetos culturais - livros, jornais e revistas -, bem como à quantidade de atividades e reuniões compartilhadas com os pais. Foram obtidas ainda evidências de associação entre os recursos do ambiente familiar e o grau de escolaridade das mães, porém não foram observadas associações com nível socioeconômico das famílias.

Steensel (2006) analisou a relação entre o ambiente familiar e o desempenho na fase de alfabetização em 116 crianças de 19 escolas primárias em uma cidade da Holanda. Os resultados revelaram que a participação dos pais nas atividades de leitura e escrita dos filhos fez com que as crianças obtivessem notas altas nas medidas de desempenho para a alfabetização. Steensel (2006) também comparou habilidades de vocabulário e compreensão de leitura entre alunos com bom rendimento e com menor rendimento e revelou que esse desempenho estava relacionado à maior pontuação no Home literacy environment (questionário aplicado 
aos pais contendo questões sobre as atividades de alfabetização desenvolvidas com a criança). $\mathrm{O}$ autor concluiu que pais que desenvolvem mais atividades que estimulam a leitura e a escrita de seus filhos podem contribuir para um melhor resultado das crianças na escola.

Brooking e Roberts (2007), em seu relatório de pesquisa preparado para o Ministério da Educação, apresentaram a informação de que $80 \%$ das escolas envolvidas no programa implantado na Nova Zelândia, denominado Home-school partnerships: literacy programme (HSPL), tiveram impacto positivo no envolvimento dos pais no aprendizado de leitura das crianças participantes.

Weiss et al. (2009) indicam a importância da participação da família no processo de aquisição da linguagem e no desenvolvimento cognitivo, realizando atividades de leitura compartilhada, entre outras.

Medeiros et al. (2000, 2003) afirmam que entre os fatores psicossociais relacionados à aprendizagem escolar estão os conceitos de autoeficácia (crença do indivíduo sobre a sua capacidade de desempenho em atividades específicas) e motivação para aprender, visto que a crença na autoeficácia, além de modificar regras de pensamento, determina o nível de motivação, bem como as crenças das crianças sobre as causas do sucesso ou fracasso escolar, suas percepções em relação às próprias habilidades para as aprendizagens específicas, suas metas, competências acadêmicas, além das estratégias metacognitivas.

Em estudo que investigou os recursos familiares e sua relação com o desempenho na compreensão de leitura de 404 alunos do $3^{\circ}$ ao $5^{\circ}$ ano do Ensino Fundamental de escolas públicas e particulares, Monteiro e Santos (2013) revelaram que a família e a escola constituem sistemas de suporte que dão à criança condições para enfrentar com mais segurança e possibilidade de sucesso os desafios da aprendizagem. Demonstraram também que a correlação identificada entre os recursos materiais no ambiente 
físico e os escores dos testes de compreensão leitora $(r=0,43)$ sugerem que a disponibilidade de livros, jornais, revistas e brinquedos promotores do desenvolvimento favorecem a compreensão de leitura.

Em que pese a literatura apresentar estudos objetivando a detecção de diversos fatores e variáveis intervenientes no processo de aprendizagem, destaca-se a importância de considerar pesquisas específicas sobre fatores capazes de gerar influência, como os psicossociais e familiares, para a compreensão do desempenho em leitura.

Os recursos do ambiente familiar, embora possam ser compreendidos como variáveis socioambientais, no estudo realizado por Mendes (2014), foram considerados variáveis preditoras da aprendizagem da leitura, com base em pesquisas já descritas (MARTURANO,1999; PIRES, 2011;TRIVELLATO-FERREIRA; MARTURANO, 2008; FERREIRA; BARRERA, 2010). Do mesmo modo, alguns autores que avaliaram variáveis psicossocioambientais e analisaram suas relações com o rendimento em leitura incluíram como variáveis a participação dos pais no processo de desenvolvimento dos filhos, a interação entre pais e filhos, o uso da linguagem no lar, as práticas educativas (MARTURANO, 1999), o ambiente doméstico favorável a práticas de leitura (STEENSEL, 2006; CAMPBELL, 2011; BROOKING; ROBERTS, 2007) e práticas parentais positivas (TRIVELLATO-FERREIRA; MARTURANO, 2008). Assim, é possível inferir que as práticas parentais favoráveis à leitura compartilhada, leitura de histórias infantis, acompanhamento das tarefas escolares e atividades em que haja a produção de linguagem na interação entre as crianças e seus pais podem interferir em resultados que apontem para correlações significativas e fortes entre variáveis psicossocioambientais e desempenho em leitura.

Situações desfavoráveis, como alteração sensorial, retardo mental, distúrbio emocional e/ou social, ou ainda influências am- 
bientais, podem causar alteração nas habilidades de leitura. Silva e Capellini (2011) desenvolveram um estudo que tinha como objetivo correlacionar as variáveis erros, tempo, velocidade e compreensão de leitura nos escolares com distúrbio de aprendizagem em relação aos escolares sem dificuldade de aprendizagem e concluíram que, para escolares com distúrbio, o desempenho nas variáveis correlacionadas encontra-se alterado, o que interfere no desenvolvimento em leitura e, consequentemente, na compreensão do texto lido. Não serão explorados no estudo ora proposto mais detalhes acerca das questões que prejudicam a aprendizagem da leitura.

Os resultados da pesquisa realizada por Mendes (2014), no que tange ao suporte e aos recursos do ambiente familiar como preditores para a aprendizagem da leitura, podem ser detectados a partir da correlação entre testes de leitura, recursos e suporte do ambiente familiar, como proporcionar atividades e passeios fora do período escolar, ter brinquedos e livros disponíveis em casa, acompanhar a criança em tarefas escolares realizadas em casa, por meio do inventário de recursos do ambiente familiar (RAF), elaborado por Marturano (2006) e adaptado por Mendes (2014). Tal inventário tem como objetivo possibilitar um levantamento de recursos do ambiente familiar que podem contribuir para o aprendizado escolar nos anos iniciais do Ensino Fundamental e peculiaridades ambientais locais. Esse questionário foi composto, na primeira parte, por itens como profissão do pai e da mãe, posição da criança na família (filho mais velho, mais novo, intermediário ou filho único) e escolaridade do pai e da mãe - questão que apresentou informações variadas, como analfabeto, Ensino Fundamental I incompleto, Ensino Fundamental completo, Ensino Médio incompleto ou completo, Ensino Superior completo ou incompleto.

$\mathrm{Na}$ segunda parte, são propostas 10 questões pautadas no RAF (MARTURANO, 2006) abordando as seguintes temáticas: o que a criança faz quando não está na escola, suas atividades 
regulares, seus últimos passeios, as atividades que os pais desenvolvem com ela em casa, os brinquedos que ela tem ou já teve, se existem jornais, revistas e livros em casa, se alguém acompanha a criança nos afazeres da escola, se ela tem uma rotina estabelecida para tomar banho, almoçar, brincar, fazer lição de casa etc., se a família tem o costume de se reunir nas refeições, aos finais de semana etc. Essas questões compuseram um escore de recursos do ambiente familiar e cada uma foi pontuada de acordo com o número de itens que constam na referida questão.

Na Tabela 3, é possível verificar a correlação observada no estudo já citado de Mendes (2014) entre testes de leitura e recursos do ambiente familiar.

TABELA 3 • CORRELAÇÃO ENTRE TESTES DE LEITURA E RECURSOS DO AMBIENTE FAMILIAR

\begin{tabular}{c|c|c|c|c|c|c} 
& & $\begin{array}{c}\text { TOTAL } \\
\text { ATIV. }\end{array}$ & $\begin{array}{c}\text { TOTAL } \\
\text { PASSEIOS }\end{array}$ & BRINQUEDOS & $\begin{array}{c}\text { TIP. } \\
\text { LIVROS }\end{array}$ & $\begin{array}{c}\text { ACOMP. CÇA. } \\
\text { TAREFAS } \\
\text { ESCOLA }\end{array}$ \\
\hline SCSE & $\mathrm{r}$ &, 121 &, 147 &, $199 *$ &, 140 &, 141 \\
\hline SCSF & $\mathrm{r}$ &, 087 &, $170 *$ &, 042 &, 092 &, 111 \\
\hline PB - Leitura & $\mathrm{r}$ &, 132 &, $168 *$ &, 100 &, 122 &, 063 \\
\hline TCLPP & $\mathrm{r}$ &, 119 &, 141 &, $\mathbf{2 0 5 *}$ &, 127 &, 111
\end{tabular}

* Correlação é significativa ao nível de 0,05.

$\mathrm{N}=142 ; \mathrm{PB}-$ Leitura = Provinha Brasil - Leitura SCSE $=$ Subteste de Compreensão de Sentença Escrita; SCSF = Subteste de Compreensão de Sentença Falada; TCLPP = Teste de Competência de Leitura de Palavras e Pseudopalavras; Total ativ. $=$ Total de atividades realizadas fora do período escolar; Total passeios $=$ Total de passeios que a criança realizou nos últimos 12 meses; Brinquedos = Total de brinquedos que a criança tem ou já teve; Tip. livros = Tipos de livros; Acomp. cça. tarefas escola = Acompanhamento da criança nas tarefas escolares.

FONTE: ELABORADA PELOS AUTORES.

Os resultados apontam que existe uma correlação positiva e significativa entre testes de leitura - Subteste de Compreensão de Sentença Escrita (SCSE) e Teste de Competência de Leitura de Palavras e Pseudopalavras (TCLPP) - e o suporte do ambiente familiar (brinquedos). 
Os resultados do referido estudo sugerem que a presença de brinquedos no ambiente familiar pode ser um preditor para a competência leitora. Assim, os resultados coadunam com as pesquisas realizadas por Marturano (1999) e Ferreira e Barrera (2010), no que tange à influência da presença de brinquedos no ambiente familiar. Há correlação significativa entre o desempenho no SCSE e a presença de brinquedos no ambiente familiar $(r=0,19)$, bem como correlação de $r=0,20$ entre o desempenho no TCLPP e o quesito brinquedos, como apontado por Monteiro e Santos (2013). Isso significa que a oferta de brinquedos no ambiente familiar está ligada ao resultado em competência em leitura.

A partir disso, pode-se inferir que uma análise mais detalhada das variáveis de suporte do ambiente familiar, tais como a qualidade de interação entre os pais e as crianças, a frequência de diálogos desenvolvidos nos momentos de convivência, assim como da leitura de livros de histórias, de contar histórias, de conversar sobre a rotina do dia anterior, de falar sobre notícias ou programas de TV, de ouvir histórias da criança e conversar sobre os assuntos que ela traz, é fundamental para a aquisição da competência leitora. Tais atividades foram elencadas na pergunta sobre as atividades que os pais desenvolviam com a criança em casa. Porém, essas interações poderiam ser, em estudos futuros, investigadas detalhadamente, de tal sorte que fosse possível apontar resultados diferentes ao comparar famílias em que pais realizem tais atividades com maior frequência às famílias que fazem isso em menor quantidade.

Os estudos que tratam do envolvimento dos pais, estilos parentais e organização no lar, em geral, enfatizam os efeitos positivos de práticas e recursos promotores do desenvolvimento da competência em leitura (MARTURANO, 1999; TRIVELLATO-FERREIRA; MARTURANO, 2008; FERREIRA; BARRERA, 2010; SANTOS; GRAMINHA, 2005; ENRICONE; SALLES, 2011; PICCOLO et al., 2012). No entanto, no estudo de Mendes 
(2014), as variáveis que tratam do envolvimento dos pais, estilos parentais e organização no lar foram avaliadas por meio de perguntas que investigavam as atividades desenvolvidas pelos pais com as crianças sem detalhar a frequência e a quantidade das interações ocorridas. Isso pode explicar a divergência entre os achados deste estudo e os dos demais citados.

Cabe salientar que, de acordo com os dados de Mendes (2014), foi possível verificar que $76,7 \%$ das crianças do $3^{\circ}$ ano do Ensino Fundamental pesquisadas nas quatro escolas recebiam o acompanhamento da família no estudo, e que o rendimento de $79,57 \%$ era acompanhado pela família.

Desse modo, pode-se afirmar que o contexto familiar é um sistema de suporte de que a criança dispõe para enfrentar os desafios da aprendizagem, principalmente da leitura.

Como diz Szymanski (2007), a escola e a família são instituições que têm em comum a preparação da criança e do jovem para o envolvimento social, sendo ambos os grupos pontos de referência nos quais vivemos e atuamos. É função da escola, além de educar os jovens, ensinar os conteúdos específicos dos diversos ramos do conhecimento, o que a diferencia da função da família, que tem uma ação educativa voltada para a construção de valores, sentimentos e emoções.

\section{Aspecto cognitivo: nomeação automática rápida de estímulos visuais e aquisição da competência em leitura}

A nomeação automática rápida de estímulos visuais está ligada à velocidade de leitura e fluência. Nomeação rápida é um processo complexo que requer a combinação de habilidades cognitivas como atenção, processos perceptuais, memória lexical e articulação.

Segundo Capellini et al. (2007), entende-se por nomeação automática rápida a capacidade de o indivíduo identificar e reco- 
nhecer um objeto, ativar o seu nome e produzi-lo oralmente o mais rápido possível. A identificação e o reconhecimento acontecem por meio da distinção da aparência, traçado, orientação e disposição do objeto.

Pesquisadores apontam que há relação entre nomeação rápida e leitura (BOWERS, 1995; CORNWALL, 1992; MORRIS et al., 1998 apud SANTOS, 2007). Cardoso-Martins e Pennington (2001), Bicalho e Alves (2010), Silva et al. (2012), Rosal (2014) entre outros, assim como Capovilla et al. (2007), relatam a habilidade de nomeação como uma habilidade essencial para o desenvolvimento da linguagem oral, relacionada à aquisição da linguagem escrita.

Cabe ressaltar que a nomeação rápida exalta a precisão, a rapidez e a fluência, características necessárias para um bom desempenho na leitura e na escrita, ou seja, poderá ser um bom preditor para a leitura.

Cardoso-Martins e Pennington (2001) afirmam que a nomeação seriada rápida contribui para a variação na habilidade de leitura e escrita independentemente da consciência de fonemas. Essa pesquisa investigou a correlação entre a nomeação seriada rápida e as habilidades de leitura e escrita em 146 crianças e adolescentes norte-americanos entre 7 e 18 anos de idade.

Em estudo realizado por Bicalho e Alves (2010), cujo objetivo era investigar a nomeação seriada rápida em crianças de escolas pública e privada, com e sem queixas de problemas escolares, concluiu-se que a capacidade de nomeação seriada pode ser considerada uma das habilidades fundamentais para o bom desempenho em leitura.

Silva et al. (2012) avaliaram 32 escolares da $4^{\underline{a}}$ série do Ensino Fundamental (atualmente $5^{\circ}$ ano) na prova de nomeação rápida do Teste de Desempenho Cognitivo-Linguístico, versão individual, e em testes de leitura e compreensão para comparar e correlacionar o desempenho dos alunos. Eles concluíram que a 
defasagem na realização das atividades de nomeação, leitura e compreensão na primeira avaliação ocasionou falhas no mecanismo de conversão fonema-grafema, que podem ser suficientes para desencadear dificuldades na aprendizagem da leitura.

Rosal (2014) investigou as contribuições da consciência fonológica e nomeação seriada rápida para aprendizagem inicial da leitura e escrita. Os resultados encontrados evidenciaram a existência de uma correlação entre a consciência fonológica e a nomeação seriada rápida e a escrita.

Capellini e Lanza (2010) compararam o desempenho de escolares do ensino público com e sem dificuldades de aprendizagem em consciência fonológica, NAR, leitura e escrita. Foi verificado que os escolares sem dificuldade de aprendizagem apresentaram melhor desempenho na nomeação automática rápida e na consciência fonológica.

Diante disso, ressalta-se que os aspectos cognitivos são importantes na aquisição da competência em leitura (MARTURANO, 1999; TRIVELLATO-FERREIRA; MARTURANO, 2008; FERREIRA; BARRERA, 2010; SANTOS; GRAMINHA, 2005; ENRICONE; SALLES, 2011; PICCOLO et al., 2012; SEABRA; DIAS, 2012). Esses aspectos abrangem linguagem, atenção para entender e interpretar a língua escrita, memória auditiva, memória visual, identificação de palavras, análise estrutural e contextual da língua, síntese lógica, expansão do vocabulário, compreensão e fluência na leitura.

Para avaliar a nomeação automática rápida, Mendes (2014) utilizou como instrumento o teste de nomeação automática rápida (SILVA; MACEDO, 2013), que tem como objetivo estimar a habilidade do indivíduo de ver um símbolo visual e nomeá-lo acurada e rapidamente. O teste é aplicado individualmente à criança e é composto por quatro subtestes: cores, objetos, letras e números. Os estímulos apresentam alta frequência na língua portuguesa e são repetidos randomicamente 10 vezes em cada 
uma das cinco linhas, totalizando 50 estímulos por prancha. As pranchas representam os subtestes. Em todos os subtestes, o examinador pergunta o nome de cada estímulo e solicita que o sujeito nomeie cada item o mais rapidamente possível sem cometer nenhum erro. São computados o número de erros e o tempo total de nomeação para todos os itens da prancha, diferentemente da versão original do teste, em que é levado em consideração somente o tempo de nomeação total dos itens.

1 Subteste 1: cores. O subteste é formado por cinco cores impressas em retângulos médios, escolhidas por apresentarem estrutura da palavra de forma dissílaba e de fácil articulação, e por serem consideradas de alta frequência linguística. São as cores: azul, rosa, marrom, verde e preto.

2 Subteste 2: objetos. O subteste é formado por cinco figuras impressas em preto e branco e de tamanho médio. Apresentam estrutura da palavra de fácil articulação, alta frequência linguística e semântica e são monossílabos ou dissílabos, segundo o português. São os objetos: lápis, cama, sol, gato e mão.

3 Subteste 3: letras. As letras foram impressas em tamanho médio e em estilo Times New Roman em maiúsculo e bastão. As letras são as mesmas da versão original, mas com estilo impresso diferente. São formadas por vogais e consoantes e apresentadas de maneira aleatória, fora da sequência alfabética. São as letras: O, A, D, P e S.

4 Subteste 4: números. Os números foram impressos e escolhidos como a versão original do teste (WOLF; DENCKLA, 2005 apud SILVA; MACEDO, 2013). São eles: 7, 4, 2, 9 e 6.

Esse teste foi aplicado individualmente em 142 crianças nas próprias escolas, em local apropriado e silencioso, durante o período escolar regular, onde foi realizada a pesquisa desenvolvida por Mendes (2014). 
$\mathrm{Na}$ Tabela 4, é possível verificar a média, o desvio padrão e o tamanho da amostra $(\mathrm{N})$ do tempo total, em segundos, despendido para finalização da tarefa, e quantidade total de erros no teste de nomeação automática rápida por escola pesquisada em quatro zoneamentos distintos.

TABELA 4 • ANÁLISE DESCRITIVA DO TEMPO GASTO EM SEGUNDOS PARA A REALIZAÇÃO DO TESTE DE NOMEAÇÃO AUTOMÁTICA RÁPIDA DE UMA AMOSTRA DE ALUNOS DO 3ํ ANO DO ENSINO FUNDAMENTAL DE QUATRO ESCOLAS DAS ZONAS LESTE, CENTRAL, NOROESTE E EM MORROS DO MUNICÍPIO DE SANTOS

\begin{tabular}{|c|c|c|c|c|c|c|}
\hline \multicolumn{2}{|c|}{ ESCOLA } & $\mathbf{N}$ & MÉDIA & DESVIO & MÍNIMO & MÁXIMO \\
\hline \multirow{5}{*}{$\begin{array}{c}\text { NAR } \\
\text { Total tempo } \\
\text { em segundos } \\
\text { nos } \\
4 \text { subtestes }\end{array}$} & 1- Zona Leste & 34 & 169,47 & 46,307 & 109 & 342 \\
\hline & 2- Zona Central & 42 & 190,81 & 53,433 & 131 & 367 \\
\hline & $\begin{array}{l}\text { 3- Zona } \\
\text { Noroeste }\end{array}$ & 32 & 190,38 & 77,119 & 131 & 516 \\
\hline & 4- Zona Morros & 34 & 186,12 & 40,942 & 132 & 291 \\
\hline & Total & 142 & 184,48 & 55,738 & 109 & 516 \\
\hline \multirow{4}{*}{$\begin{array}{c}\text { NAR } \\
\text { Total erro nos } \\
4 \text { subtestes }\end{array}$} & 1- Zona Leste & 34 &, 53 & 1,376 & 0 & 7 \\
\hline & 2- Zona Central & 42 & 3,48 & 7,626 & 0 & 40 \\
\hline & $\begin{array}{c}\text { 3-Zona } \\
\text { Noroeste }\end{array}$ & 32 & 2,91 & 7,973 & 0 & 44 \\
\hline & 4- Zona Morros & 34 & 3,41 & 6,716 & 0 & 35 \\
\hline \multicolumn{2}{|c|}{ Total } & 142 & 2,63 & 6,582 & 0 & 44 \\
\hline
\end{tabular}

NAR = prova de nomeação automática rápida: subtestes cores, objetos, letras e números - tempo total em segundos e total de erros.

FONTE: ELABORADA PELOS AUTORES.

Houve diferenças entre as médias dos grupos de cada zoneamento em relação ao tempo total gasto para realizar a prova de nomeação automática rápida de cores, objetos, letras e números. As crianças da escola Zona Leste apresentaram menor tempo médio em relação à escola Zona Central. A escola Zona Leste apresentou menor quantidade de erros na tarefa, enquanto 
a escola Zona Noroeste apresentou maior número de erros na mesma tarefa.

O aspecto cognitivo de nomeação automática rápida de cores, objetos, letras e números apresentou correlação significativa com testes de leitura. Os coeficientes identificados nos resultados são negativos, o que demonstra que quanto maior o tempo de nomeação menor o domínio nas habilidades de leitura.

Com base nessa constatação, cabe salientar aos profissionais que atuam no processo de ensino e aprendizagem de crianças a importância desse aspecto cognitivo para a aprendizagem das habilidades de leitura. Assim, esses profissionais podem aplicar atividades de nomeação rápida em sala de aula a fim de desenvolver as habilidades de leitura. 


\section{Contexto escolar: sistema de avaliação e competência em leitura}

\section{Contexto escolar}

O Ministério da Educação, por meio da Secretaria de Educação Básica, define como objetivos da Educação Infantil e do Ensino Fundamental:

[...] o desenvolvimento da capacidade de aprender, tendo como meios básicos o pleno domínio da leitura, da escrita e do cálculo [...], bem como [...] foco central na alfabetização, ao longo dos três primeiros anos [...] (BRASIL, 2013).

No que se refere à conquista da competência em leitura e escrita, o Ministério da Educação propõe que, além da inserção dos alunos em um ambiente com acesso aos diversos usos da leitura e da escrita, é necessário um trabalho sistemático, centrado tanto nos aspectos funcionais e textuais quanto no aprendizado dos aspectos gráficos da linguagem escrita e daqueles referentes ao sistema alfabético de representação (BRASIL, 2004). 
Assim, nessa perspectiva da avaliação da competência em leitura, será verificado o contexto escolar de um estudo realizado por Mendes (2014) em quatro escolas municipais que oferecem o Ensino Fundamental, em um município situado na região Sudeste, litoral do estado de São Paulo. As escolas estão localizadas nas zonas Leste, Central, Noroeste e em morros da cidade de Santos que a caracterizam como um todo.

As unidades municipais de educação (UME) de Santos que atendem o Ensino Fundamental estão enquadradas, segundo a escala de medição da infraestrutura escolar (NETO et al., 2013), no nível adequado, conforme dados obtidos na Secretaria Municipal de Educação de Santos. Nesse nível, as escolas têm em sua infraestrutura: água, sanitário, energia, esgoto, cozinha, sala de diretoria, sala de professores, biblioteca, laboratório de informática, quadra e/ou local que permite convívio social e desenvolvimento motor, equipamentos de TV, DVD, computadores, impressora, copiadora e acesso à internet.

Ainda de acordo com os pesquisadores, a escala de infraestrutura possibilita análises relevantes, visto que estudos demonstraram que as condições físicas e o ambiente escolar são variáveis que impactam a proficiência em todas as regiões brasileiras.

As escolas que participaram desse estudo enquadram-se no nível adequado, conforme dados obtidos em relatórios Censo/2013, no Departamento de Infraestrutura da Secretaria Municipal de Educação de Santos.

Participaram da pesquisa: 34 alunos da Zona Leste, 42 da Zona Central, 32 da Zona Noroeste e 34 da Zona Morros.

\section{Sistema de avaliação no desempenho de leitura e escrita}

A qualidade do ensino tem sido motivo de preocupação nas esferas municipal, estadual e federal. Por essa razão, o governo brasileiro instituiu avaliações oficiais, padronizadas e em larga escala com o objetivo de acompanhar o rendimento dos alunos matriculados nas 
redes oficiais de ensino. Desde a década de 1990, o desenvolvimento das avaliações em grande escala tem se voltado a subsidiar a elaboração de diagnósticos sobre a realidade educacional e a orientação para formular políticas públicas visando à promoção da equidade e da melhoria do ensino brasileiro (SOUSA; ARCAS, 2010). É fundamental que as avaliações em grande escala de fato contribuam para a melhoria do processo de ensino e aprendizagem, de modo que os brasileiros, sejam crianças, adolescentes ou adultos, adquiram as habilidades e competências necessárias à leitura e escrita.

Ocorre que, mesmo com os avanços recentemente divulgados pelo MEC por meio do Ideb, os indicadores em Língua Portuguesa apurados pela média total na Prova Brasil 2011, nos anos iniciais do Ensino Fundamental, refletem 190,6 de um total de 350 pontos. Esse resultado está enquadrado no nível 3 de desempenho em leitura, conforme a escala de desempenho de Língua Portuguesa Ensino Fundamental, que vai até o nível 9 (BRASIL, 2011).

Para apurar detalhadamente a Educação Básica, a Prova Brasil foi regulamentada em 2005, por meio da Portaria Inep nº 69. As escolas públicas localizadas na zona urbana devem se submeter a essa prova, cujo objetivo é avaliar a qualidade do ensino ministrado nesses locais. A aplicação ocorre para alunos de $5^{\circ}$ e $9^{\circ}$ anos do Ensino Fundamental, anteriormente denominados $4^{\underline{a}}$ e $8^{\underline{a}}$ séries. Os testes aos quais os alunos são submetidos são de Língua Portuguesa e Matemática.

Os resultados da Prova Brasil são apresentados em uma escala de desempenho por disciplina. A escala de Língua Portuguesa é composta por nove níveis: 125, 150 e assim sucessivamente até o nível 9, com um total de 350 pontos. Os níveis são constituídos por habilidades individuais acrescidas às dos níveis anteriores.

O Quadro 1 descreve os níveis da escala de desempenho de Língua Portuguesa da Prova Brasil.

No estado de São Paulo, os resultados da Prova Brasil 2011 Língua Portuguesa apontam como média total (rede pública e privada) 
QUADRO 1 •ESCALA DE DESEMPENHO DE LÍNGUA PORTUGUESA DA PROVA BRASIL

\begin{tabular}{|c|c|}
\hline $\begin{array}{c}\text { NÍVEIS DE } \\
\text { DESEMPENHO } \\
\text { DOS ALUNOS } \\
\text { EM LEITURA }\end{array}$ & 0 QUE OS ALUNOS CONSEGUEM FAZER NESSE NÍVEL \\
\hline $\begin{array}{l}\text { NÍVEL } 0 \text { - } \\
\text { ABAIXO } \\
\text { DE } 125\end{array}$ & $\begin{array}{l}\text { A Prova Brasil não utilizou itens que avaliam as habilidades abaixo deste nível. } \\
\text { Os alunos localizados abaixo do nível } 125 \text { requerem atenção especial, pois } \\
\text { não demonstram habilidades muito elementares, como as de: } \\
\text { - localizar informação (exemplo: o personagem principal, local e tempo } \\
\text { da narrativa); } \\
\text { - identificar o efeito de sentido decorrente da utilização de recursos } \\
\text { gráficos (exemplo: letras maiúsculas chamando a atenção em um cartaz); } \\
\text { - identificar o tema, em um texto simples e curto. }\end{array}$ \\
\hline $\begin{array}{l}\text { NÍVE } \\
125 \mathrm{~A}\end{array}$ & $\begin{array}{l}\text { Os alunos de } 5^{0} \text { e } 9^{0} \text { anos ( } 4^{a} \text { e } 8^{\underline{a}} \text { séries): } \\
\text { - localizam informações explícitas em textos narrativos curtos, } \\
\text { informativos e anúncios; } \\
\text { - } \quad \text { identificam o tema de um texto; } \\
\text { - } \quad \text { localizam elementos como o personagem principal; } \\
\text { - } \quad \text { estabelecem relação entre partes do texto: personagem e ação; ação } \\
\text { e tempo; ação e lugar. }\end{array}$ \\
\hline $\begin{array}{l}\text { NÍVEL } 2 \text { - } \\
150 \text { A } 175\end{array}$ & 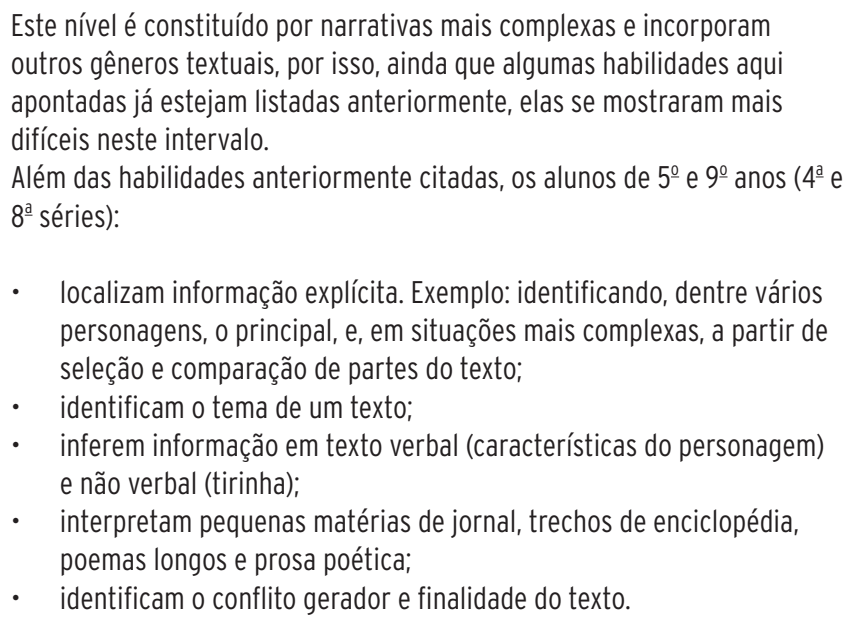 \\
\hline $\begin{array}{l}\text { NÍVEL } 3 \text { - } \\
175 \text { A } 200\end{array}$ & $\begin{array}{l}\text { Além das habilidades anteriormente citadas, os alunos de } 5^{0} \text { e } 9^{0} \text { anos ( } 4^{\text {a }} \text { e } \\
8^{\text {a }} \text { séries): } \\
\text { - interpretam, a partir de inferência, texto não verbal (tirinha) de maior } \\
\text { complexidade temática; }\end{array}$ \\
\hline
\end{tabular}


QUADRO 1 • ESCALA DE DESEMPENHO DE LÍNGUA PORTUGUESA DA PROVA BRASIL (CONTINUAÇÃO)

\begin{tabular}{|c|c|}
\hline $\begin{array}{l}\text { NÍVEIS DE } \\
\text { DESEMPENHO } \\
\text { DOS ALUNOS } \\
\text { EM LEITURA }\end{array}$ & O QUE OS ALUNOS CONSEGUEM FAZER NESSE NÍVEL \\
\hline $\begin{array}{l}\text { NÍVEL } 3 \text { - } \\
175 \text { A } 200\end{array}$ & $\begin{array}{l}\text { - identificam o tema a partir de características que tratam de } \\
\text { - sentimentos do personagem principal; } \\
\text { reconhecem elementos que compõem uma narrativa com temática e } \\
\text { vocabulário complexos. }\end{array}$ \\
\hline $\begin{array}{l}\text { NÍVE } \\
200\end{array}$ & 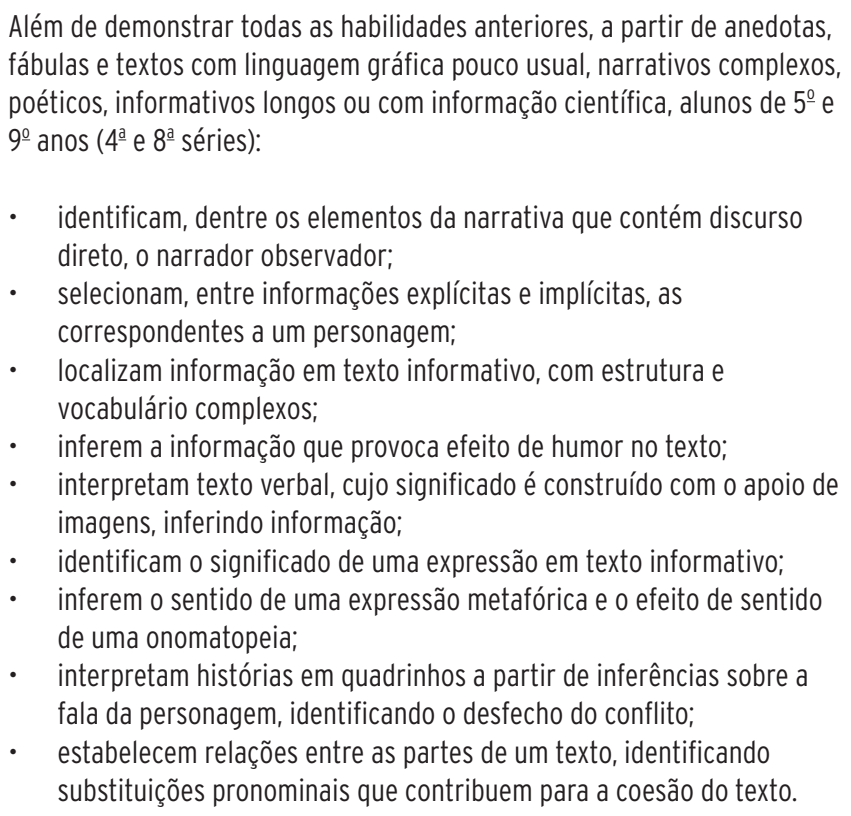 \\
\hline $\begin{array}{l}\text { NÍVEL } 5 \text { - } \\
225 \text { A } 250\end{array}$ & $\begin{array}{l}\text { Além das habilidades anteriores, os alunos de } 5^{0} \text { e } 9^{0} \text { anos ( } 4^{a} \text { e } 8^{a} \text { séries): } \\
\text { - } \quad \text { identificam o efeito de sentido decorrente do uso da pontuação } \\
\text { (reticências); } \\
\text { - } \quad \text { inferem a finalidade do texto; } \\
\text { - } \quad \text { distinguem um fato da opinião relativa a este fato, numa narrativa } \\
\text { com narrador personagem; } \\
\text { - } \quad \text { distinguem o sentido metafórico do literal de uma expressão; } \\
\text { - } \quad \text { reconhecem efeitos de ironia ou humor em textos variados; } \\
\text { - identificam a relação lógico-discursiva marcada por locução adverbial } \\
\text { - } \quad \text { in conjunção comparativa; } \\
\text { - } \quad \text { localizam a informação principal. }\end{array}$ \\
\hline
\end{tabular}


QUADRO 1 • ESCALA DE DESEMPENHO DE LÍNGUA PORTUGUESA DA PROVA BRASIL (CONTINUAÇÃO)

\begin{tabular}{|c|c|}
\hline $\begin{array}{c}\text { NÍVEIS DE } \\
\text { DESEMPENHO } \\
\text { DOS ALUNOS } \\
\text { EM LEITURA }\end{array}$ & 0 QUE OS ALUNOS CONSEGUEM FAZER NESSE NÍVEL \\
\hline $\begin{array}{l}\text { NÍVEL } 5 \text { - } \\
225 \text { A } 250\end{array}$ & $\begin{array}{l}\text { Os alunos de } 9^{0} \text { ano ( } 8^{\text {a }} \text { série), neste nível, ainda: } \\
\text { - inferem o sentido de uma palavra ou expressão; } \\
\text { - estabelecem relação causa/consequência entre partes e elementos } \\
\text { do texto; } \\
\text { - identificam o tema de textos narrativos, argumentativos e poéticos de } \\
\text { conteúdo complexo; } \\
\text { - identificam a tese e os argumentos que a defendem em textos } \\
\text { - } \text { argumentativos; } \\
\text { reconhecem o efeito de sentido decorrente da escolha de uma } \\
\text { determinada palavra ou expressão. }\end{array}$ \\
\hline $\begin{array}{l}\text { NÍVEL } 6 \text { - } \\
250 \text { A } 275\end{array}$ & 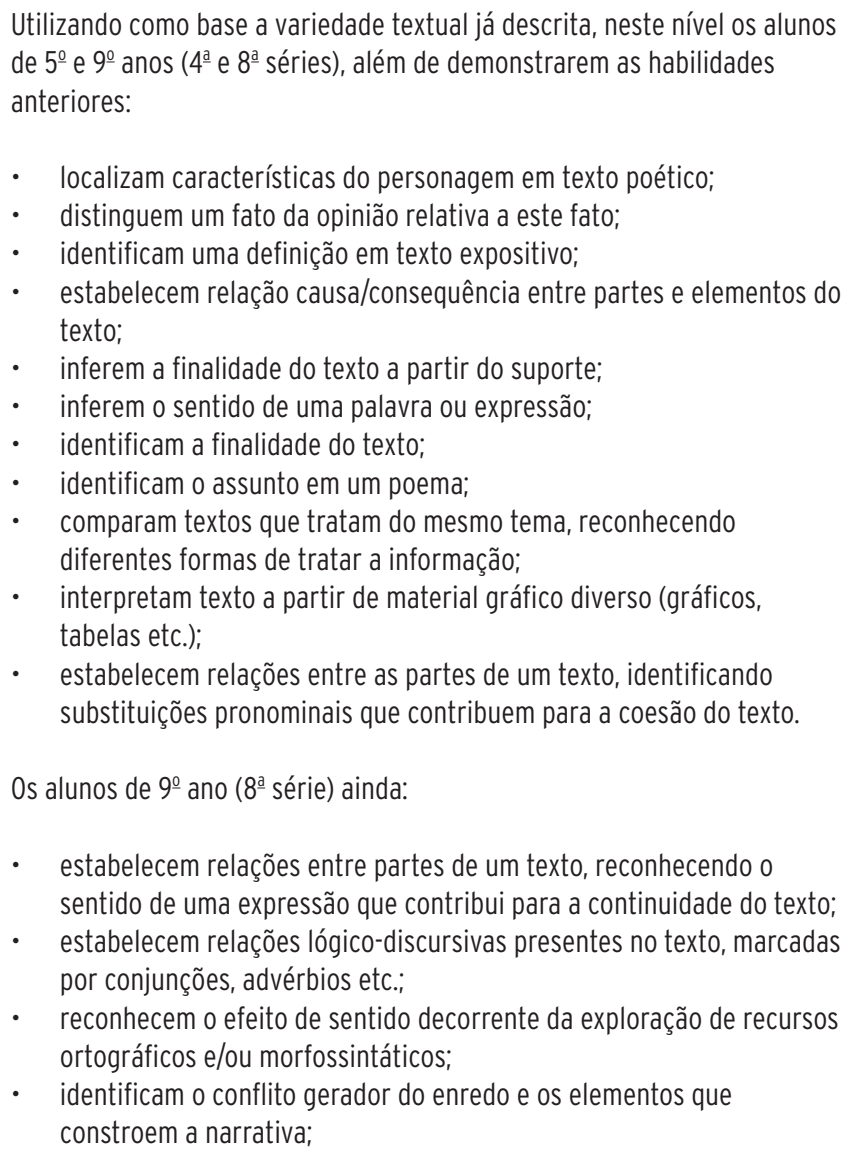 \\
\hline
\end{tabular}


QUADRO 1 • ESCALA DE DESEMPENHO DE LÍNGUA PORTUGUESA DA PROVA BRASIL (CONTINUAÇÃO)

\begin{tabular}{|c|c|}
\hline $\begin{array}{c}\text { NÍVEIS DE } \\
\text { DESEMPENHO } \\
\text { DOS ALUNOS } \\
\text { EM LEITURA }\end{array}$ & 0 QUE OS ALUNOS CONSEGUEM FAZER NESSE NÍVEL \\
\hline $\begin{array}{l}\text { NÍVEL } 6 \text { - } \\
250 \text { A } 275\end{array}$ & $\begin{array}{l}\text { - identificam a tese e o argumento que defendem em texto com a } \\
\text { - } \quad \text { inguagem informal; } \\
\text { longos; } \\
\text { - } \quad \text { inferem efeitos de ironia ou humor em narrativas curtas; } \\
\text { - inferem o sentido de uma expressão em texto narrativo longo e de } \\
\text { vocabulário complexo. }\end{array}$ \\
\hline $\begin{array}{l}\text { NÍV } \\
275\end{array}$ & 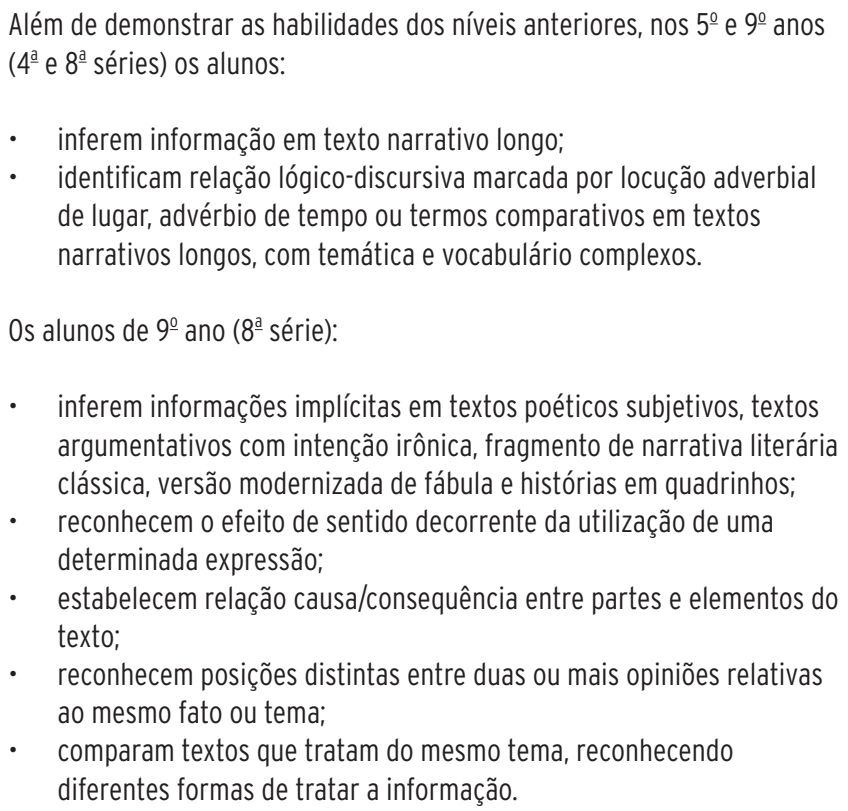 \\
\hline $\begin{array}{l}\text { NÍVEI } \\
300 \mathrm{~A}\end{array}$ & 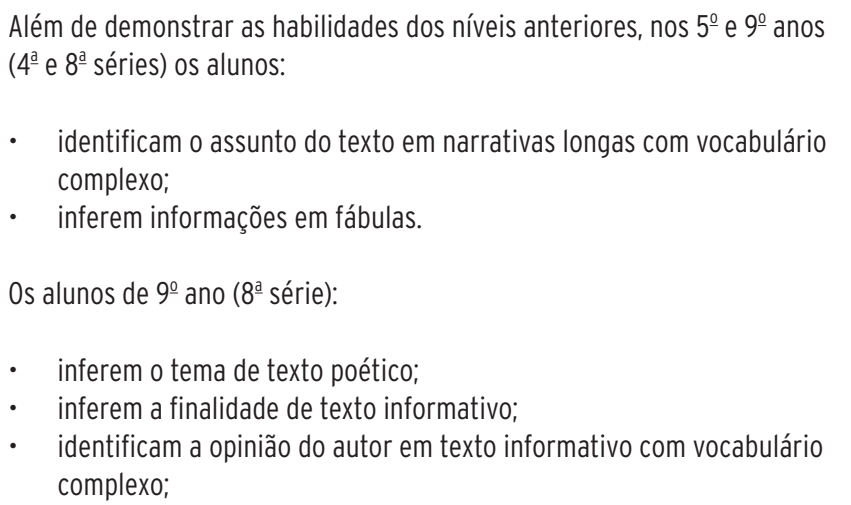 \\
\hline
\end{tabular}


QUADRO 1 • ESCALA DE DESEMPENHO DE LÍNGUA PORTUGUESA DA PROVA BRASIL (CONTINUAÇÃO)

\begin{tabular}{|c|c|}
\hline $\begin{array}{c}\text { NÍVEIS DE } \\
\text { DESEMPENHO } \\
\text { DOS ALUNOS } \\
\text { EM LEITURA }\end{array}$ & 0 QUE OS ALUNOS CONSEGUEM FAZER NESSE NÍVEL \\
\hline $\begin{array}{l}\text { NÍVEL } 8 \text { - } \\
300 \text { A } 325\end{array}$ & $\begin{array}{l}\text { - } \quad \text { diferenciam as partes principais das secundárias de um texto; } \\
\text { - } \quad \text { interpretam tabela a partir da comparação entre informações; } \\
\text { - } \quad \text { estabelecem relação entre a tese e os argumentos oferecidos para } \\
\text { - } \quad \text { idententá-la; } \\
\text { - } \quad \text { identificam a tese de um texto argumentativo; } \\
\text { - } \quad \text { reconfonflito gerador do enredo; } \\
\text { outras notações. }\end{array}$ \\
\hline $\begin{array}{l}\text { NÍVEL } 9 \text { - } \\
325 \text { A } 350\end{array}$ & $\begin{array}{l}\text { Além das habilidades descritas anteriormente, os alunos de } 9^{0} \text { ano ( } 8^{\mathrm{a}} \\
\text { série) localizados neste nível demonstram habilidades de leitura que } \\
\text { envolvem: compreensão global de texto e avaliação e estabelecimento de } \\
\text { relações entre textos e partes de textos mais longos e com vocabulário } \\
\text { complexos. Além disso, inferem informações em diversos contextos e } \\
\text { começam a ler com compreensão textos da literatura clássica. }\end{array}$ \\
\hline
\end{tabular}

FONTE: BRASIL (2011).

200,0 pontos, o que equivale ao nível 3 na escala de desempenho. Nesse nível, o aluno tem habilidade para localizar informações explícitas em textos narrativos curtos, identificar o tema do texto, inferir informação em texto verbal e não verbal, interpretar pequenas matérias de jornal, reconhecer elementos que compõem uma narrativa com temática e vocabulários complexos (BRASIL, 2011).

Para o município de Santos, os resultados apontaram 201,7 pontos, o que equivale à pontuação inicial correspondente ao nível 4. Nesse nível, o aluno tem habilidade para localizar informações explícitas em textos narrativos curtos, identificar o tema do texto, inferir informação em texto verbal e não verbal, interpretar pequenas matérias de jornal e reconhecer elementos que compõem uma narrativa com temática e vocabulários complexos. A criança também é capaz de interpretar histórias em quadrinhos a partir de inferências sobre a fala da personagem e estabelecer relações entre as partes de um texto, conforme a escala de desempenho de Língua Portuguesa no Ensino Fundamental (BRASIL, 2011). 
Nos resultados do Programa Internacional de Avaliação de Alunos (Pisa) 2009, o Brasil, em que pese a melhoria de desempenho apresentada, aparece na $55^{\underline{a}}$ posição, abaixo da média, principalmente no que tange às competências leitoras, segundo dados do Inep. Trata-se de um programa internacional de avaliação comparada, aplicado a partir da $7^{\underline{a}}$ série do Ensino Fundamental (atualmente $8^{\circ}$ ano), cujo objetivo é produzir indicadores da qualidade da educação ministrada nos países participantes, avaliando as competências dos estudantes em leitura, matemática e ciências.

Oliveira (2005) aponta que 55\% dos alunos brasileiros com 13 anos de idade, matriculados nas $7^{\underline{a}}$ e $8^{\underline{a}}$ séries do Ensino Fundamental (atualmente $8^{\circ}$ e $9^{\circ}$ anos) apresentam nível mais básico de leitura: o da identificação das palavras.

De acordo com os resultados do Saresp 2011, cerca de 71\% das escolas da rede estadual apresentaram, na avaliação dos alunos de $3^{\circ}$ ano do Ensino Fundamental, bom desempenho para leitura, conforme critério do teste, qual seja, 53,5 de um total de 72 pontos. Já na avaliação dos alunos de $5^{\circ}$ ano do Ensino Fundamental, a média foi de 195 pontos em Língua Portuguesa. Esse resultado equivale ao nível básico de proficiência e domínio mínimo dos conteúdos, das competências e das habilidades necessárias para interagir com a proposta curricular do ano subsequente.

Capellini, Tonelotto e Ciasca (2004) apontam que uma avaliação formal, inicial e referencial realizada pelo professor é um critério útil para investigação do desempenho das crianças, pois fornece elementos para verificar a coerência entre o julgamento dos professores (em avaliações não padronizadas) e os resultados de testes padronizados. Estes podem apresentar vantagens, conforme indicado por Nikaedo, Kuriyama e Macedo (2007, p. 192):

[...] os resultados não estão tão sujeitos ao julgamento subjetivo de cada professor; possibilitam caracterizar melhor o padrão de leitura 
e escrita de cada estudante; permitem a elaboração de estratégias específicas de intervenção em função das dificuldades apresentadas pelos alunos; possibilitam o estabelecimento de medidas objetivas de comparação entre escolas com metodologias e orientações pedagógicas diferentes e permitem o acompanhamento mais preciso do desenvolvimento do escolar ao longo do ano.

Em meio às iniciativas de avaliação para indicar a melhoria na qualidade de ensino e aprendizagem das crianças brasileiras, o MEC institui a Provinha Brasil, pela Portaria Normativa $\mathrm{n}^{\mathrm{o}}$ 10/2007 (BRASIL, 2007). O objetivo é diagnosticar as habilidades de leitura e letramento/alfabetização de crianças das redes públicas de Ensino Fundamental, a fim de possibilitar ações e intervenções mais efetivas na alfabetização dos alunos dos anos iniciais dessa etapa.

\section{A Provinha Brasil - Leitura}

A Provinha Brasil é um instrumento avaliativo, instituído pelo MEC em 2007, e tem a finalidade de identificar o nível de alfabetização das crianças matriculadas no $2^{\circ}$ ano do Ensino Fundamental da rede pública e diagnosticar insuficiências na leitura e na escrita.

Nessa avaliação, de acordo com as instruções do MEC, a adesão é voluntária e aberta a todas as escolas do país, com a finalidade de permitir intervenções corretoras, caso sejam diagnosticadas insuficiências em leitura e escrita dos alunos avaliados.

As avaliações em larga escala instituídas pelo MEC são construídas a partir de uma matriz de referência, isto é, documentos que orientam seu conteúdo e a elaboração das questões que a compõem (GONTIJO, 2012).

As habilidades de leitura e escrita constituintes da Provinha Brasil tiveram sua base veiculada em duas matrizes de referência: 
a primeira vigorou no ano de 2008, quando houve a aplicação do primeiro teste, e a segunda, a partir de 2009. A primeira continha três eixos: 1 . apropriação do sistema de escrita: habilidades relacionadas à identificação e ao reconhecimento de princípios do sistema de escrita; 2. leitura; 3. escrita. A matriz de referência sofreu alteração no ano de 2009, e o eixo escrita, essencial no processo de alfabetização, foi retirado do documento (GONTIJO, 2012).

As habilidades que constam na matriz de referência estão fundamentadas na concepção de que alfabetização e letramento são processos que devem ser desenvolvidos de maneira complementar e paralela. Consideram a alfabetização como o desenvolvimento da compreensão das regras de funcionamento do sistema de escrita alfabética e o letramento como as possibilidades de usos e funções sociais da linguagem escrita, isto é, como processo de inserção e participação dos sujeitos na cultura escrita (BRASIL, 2009).

A matriz de referência vigente para avaliar a alfabetização e o letramento inicial da Provinha Brasil é composta por um conjunto de 10 descritores (habilidades), distribuídos em dois eixos:

Eixo 1 - Apropriação do sistema de escrita: habilidades relacionadas à identificação e ao reconhecimento de princípios do sistema de escrita. Nesse eixo, há três descritores:

» D1: Reconhecer letras. O aluno deverá diferenciar letras de outros signos gráficos, identificar pelo menos as letras do alfabeto ou reconhecer os diferentes tipos de grafia das letras.

» D2: Reconhecer sílabas. Nesse descritor, o aluno deverá identificar o número de sílabas que formam uma palavra por contagem ou comparação das sílabas de palavras dadas por imagem.

» D3: Estabelecer relação entre unidades sonoras e suas representações gráficas. O aluno deverá identificar a representação de unidades sonoras, como letras que possuem correspon- 
dência sonora única $(p, b, t, d, f)$, letras com mais de uma correspondência sonora $(c$ e $g)$ e sílabas.

Eixo 2 - Leitura. Nesse eixo, estão contidos sete descritores:

» D4: Ler palavras. Nesse descritor a criança deverá identificar a escrita de uma palavra ditada ou ilustrada, sem que isso seja possível a partir do reconhecimento de um único fonema ou de uma única sílaba.

» D5: Ler frases. A criança deverá localizar informações em enunciados curtos e de sentido completo, sem que isso seja possível a partir das estratégias de identificação de uma única palavra que liga o gabarito à frase.

» D6: Localizar informação explícita em textos. Nesse quesito, a criança deverá localizar informação em diferentes gêneros textuais, com diferentes tamanhos, estruturas e graus de evidência da informação, o que exige, em alguns casos, que relacione dados do texto para chegar à resposta correta.

» D7: Reconhecer o assunto de um texto. Trata-se de antecipar o assunto do texto com base no suporte, nas características gráficas do gênero ou, em um nível mais complexo, reconhecer o assunto com base apenas na leitura individual do texto.

» D8: Identificar finalidades do texto. A criança deverá antecipar a finalidade do texto com base no suporte, nas características gráficas do gênero ou, em um nível mais complexo, identificar a finalidade, apoiando-se apenas na leitura individual do texto.

» D9: Estabelecer relação entre as partes do texto. A criança, nesse descritor, deverá identificar repetições e substituições que contribuem para a coerência e a coesão textuais.

» D10: Inferir informação (BRASIL, 2009).

Desde 2011, o instrumental da Provinha Brasil é constituído de um kit composto por: 
1 Caderno de teste do aluno com as questões que serão respondidas.

2 Guia de aplicação: caderno com os procedimentos de aplicação e as questões a serem aplicadas aos alunos.

3 Guia de correção e interpretação de resultados: caderno com as principais informações sobre a Provinha Brasil - seus objetivos, pressupostos teóricos e metodologia -, orientações para a correção do teste, possibilidades de interpretação e uso dos seus resultados.

4 Reflexões sobre a prática.

Desde 2011, o instrumento é composto por 20 questões de múltipla escolha, com quatro opções de resposta para cada uma. $\mathrm{O}$ avaliador propicia na aplicação três tipos de comando: totalmente lidas pelo aplicador, parcialmente lidas pelo aplicador e lidas pelo aluno individualmente. Seguindo esses comandos, é necessário verificar se a audição e a visão do avaliado estão preservadas.

O critério definido para identificar os níveis de desempenho dos alunos é obtido pelo número de acertos verificados (BRASIL, 2012d). São cinco níveis e para cada um deles foi descrito um conjunto de habilidades:

» Nível 1 - até 3 acertos: o aluno encontra-se em um estágio inicial do processo de alfabetização. Isso significa que está no início da apropriação das habilidades referentes ao domínio das regras que orientam o uso do sistema alfabético para leitura e escrita - identifica valor sonoro das partes iniciais ou finais da palavra, reconhece algumas letras do alfabeto e inicia a distinção entre letra, desenhos e outros sinais gráficos.

» Nível 2 - de 4 a 8 acertos: o aluno associa adequadamente letras e sons, estabelece relação entre grafemas e fonemas, lê palavras compostas por sílabas canônicas $(\mathrm{CV})$, lê algumas palavras compostas por sílabas não canônicas (CVC/ 
CCV) e reconhece palavras de formação silábica canônica escritas de diferentes formas.

» Nível 3 - de 9 a 13 acertos: o aluno é capaz de ler palavras de diferentes tamanhos e padrões silábicos, ler frases com sintaxe simples (sujeito + verbo + objeto) e localizar informações em uma frase ou em um texto de aproximadamente cinco linhas.

» Nível 4 - de 14 a 18 acertos: o aluno lê textos de aproximadamente oito a 10 linhas, na ordem direta, de estrutura sintática simples e de vocabulário adequado ao repertório explorado na escola, e tece inferências simples.

» Nível 5 - de 19 a 20 acertos: além de ter as habilidades dos outros quatro níveis, o aluno é capaz de compreender textos de diferentes gêneros e de complexidade diversa, identificando o assunto principal, localizando informações não evidentes e fazendo inferências.

Cabe salientar que cada um desses níveis engloba as habilidades anteriores e acrescenta novas, indicando em que ponto do processo de alfabetização os alunos se encontram.

A possibilidade de comparação entre as avaliações externas, como é o caso da Provinha Brasil - que não é um instrumento psicométrico, mas sim um instrumento padronizado e pautado em parâmetros normativos -, e a avaliação da aprendizagem realizada na prática cotidiana do professor é uma ferramenta importante para a sugestão de estratégias pedagógicas e de avaliação.

Da mesma maneira, a comparação entre avaliações oficiais, como é o caso da Provinha Brasil, e dos Parâmetros Curriculares Nacionais (PCN) pode contribuir para o entendimento das competências requeridas no desenvolvimento da leitura e da escrita, além de constatar se as propostas de verificação do rendimento escolar, tanto nas avaliações quanto nos parâmetros, estão em acordo. 
Os resultados da Provinha Brasil, que servem para apontar um diagnóstico individual do alunado, permitem calcular médias que expressem o percentual de acertos de cada uma das turmas e verificar a média obtida pelas escolas participantes.

Em Santos, a Provinha Brasil passou a ser aplicada já em sua primeira versão, em 2008. No ano de 2011, os resultados indicaram que das 36 UMEs a maior parte $(82,9 \%)$ obteve entre 16 e 18 acertos nas questões, o que corresponde ao nível 4, e 8,33\% obtiveram entre 13 e 15 acertos.

Os resultados obtidos em 2012 pelas 36 UMEs avaliadas indicaram que $83 \%$ dos alunos estavam no nível 4 , enquanto $4 \%$ encontravam-se no nível 3, e os demais, distribuídos entre os níveis 2 e 5, conforme o Quadro 1.

O Gráfico 1 apresenta as médias dos resultados obtidos pelas 36 UMEs nos anos de 2011 e 2012 na Provinha Brasil - Leitura 2. Em 2011, a média foi de 16,5 pontos e, em 2012, de 17 pontos, ou seja, as médias desses anos apontam nível médio 4.

GRÁFICO 1 • MÉDIA DOS RESULTADOS OBTIDOS EM 36 UMES NOS ANOS DE 2011 E 2012

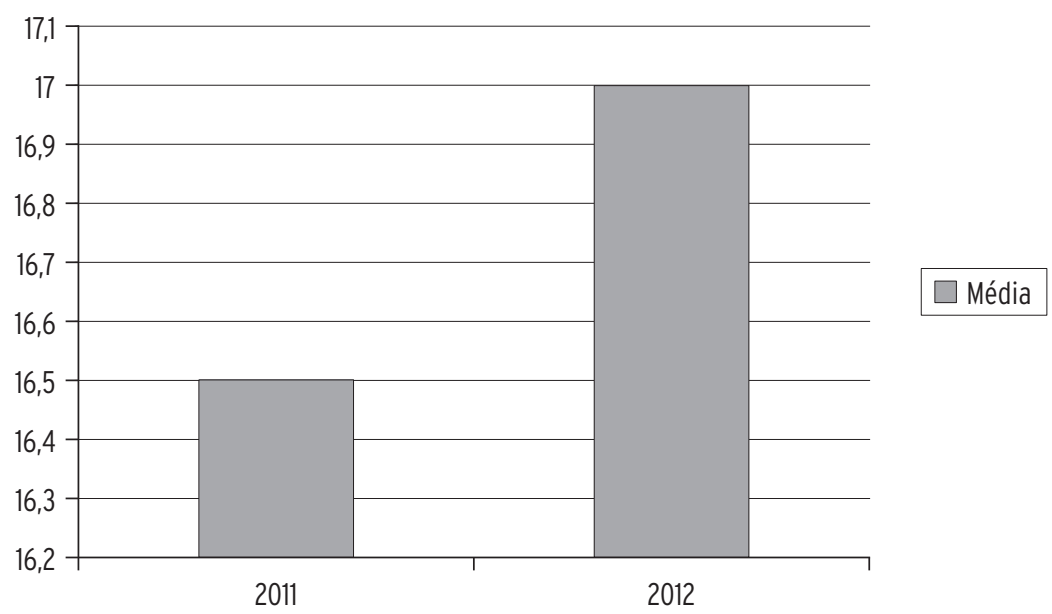

Média dos resultados obtidos na Provinha Brasil - Leitura 2: $2011=16,5 ; 2012=17$. Pontuação total: 20 pontos. 
A Provinha Brasil - Leitura 2012 - teste 2 é composta por: uma questão-exemplo, para orientar os alunos sobre como responder ao teste, e 20 questões de múltipla escolha, com quatro alternativas em cada uma. Há três tipos de enunciado nas questões:

1 totalmente lidas pelo professor/aplicador, com questões cujos enunciados e alternativas precisam ser completamente lidos pelo aplicador;

2 parcialmente lidas pelo professor/aplicador, em que serão lidos os todos os enunciados ou somente um deles. Pode também ser lido o texto para que os alunos acompanhem;

3 lidas pelos alunos individualmente. $\mathrm{O}$ aplicador deverá apenas explicar aos alunos que eles farão a leitura do texto, dos enunciados e das alternativas sozinhos. A pontuação total para esse teste é 20 pontos.

Para melhor entendimento da Provinha Brasil - Leitura 2012 - teste 2, Mendes (2013) analisa a matriz curricular da referida prova à luz da abordagem cognitiva de leitura, na qual se detecta que o primeiro bloco de questões - composto das questões 1 a 11 - tem como enfoque o desenvolvimento das habilidades de codificação e decodificação. Já o segundo bloco é composto de nove questões que envolvem a compreensão leitora a partir do conteúdo global do discurso e da retenção da informação textual. Como pode ser verificado, há oito questões do Eixo 1 que enfatizam as habilidades fonológicas, enquanto as questões de 9 a 20 são destinadas a avaliar a compreensão leitora, que requer o reconhecimento de letras, a representação fonológica da palavra, mas também o significado mais apropriado ao contexto, integrando-o ao sentido do texto para permitir que sejam tecidas inferências pautadas em seu conhecimento de mundo. Na prova, também não há questões que envolvam a leitura de pseudopalavras, reconhecida- 
mente a forma mais adequada para avaliar competências de decodificação. Em sua maioria são apresentadas palavras simples no estilo (CV, VC, CVCC), que têm regularidade e, em geral, compõem o repertório vocabular do aluno no nível de escolaridade referido para a aplicação do teste, isto é, o $2^{\underline{0}}$ ano do Ensino Fundamental. Essa avaliação não envolve leitura em voz alta, apenas silenciosa, e também não trata das questões pertinentes à escrita. Em suma, pode-se verificar que metade da Provinha Brasil enfoca as habilidades necessárias para a aquisição da competência em leitura e escrita apontadas pelo modelo teórico de leitura da abordagem cognitiva, e apenas $45 \%$ da prova trata das habilidades necessárias ao letramento.

Para a explicitação das questões, foi feita uma análise das competências e habilidades avaliadas na Provinha Brasil - Leitura sob a ótica da abordagem cognitiva de leitura, da seguinte maneira:

Nas questões de 1 a 8 , são solicitadas a identificação de grafema/fonema, letra inicial da palavra, primeira sílaba, mesma sílaba da palavra indicada por meio da imagem e do som, leitura de palavra a partir de imagem e identificação do número de sílabas, que poderá ser feita pela rota fonológica. Exemplos:

\section{Questão 1}

Observe a figura:

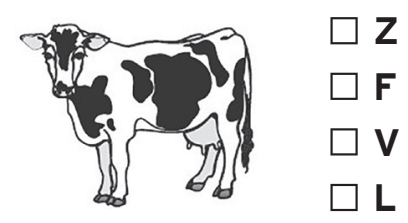

A letra V faz parte da escrita da palavra VACA. Marque um $\mathrm{X}$ no quadradinho em que aparece a letra $\mathrm{V}$. 


\section{Questão 8}

Conte o número de sílabas que tem no nome do objeto e depois marque o quadradinho que representa esse número.

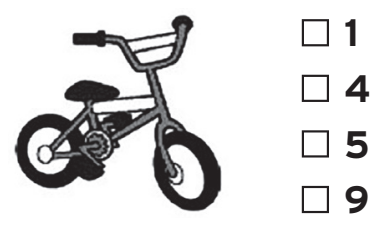

$\mathrm{Na}$ questão 9, de compreensão textual, a partir da leitura silenciosa do texto, que contém palavras e imagem, e da indicação do que o avaliador precisa fazer, o avaliado deve indicar qual das alternativas apresenta o item a ser doado.

No item 10, para a compreensão de leitura, é necessário estabelecer a correspondência entre a imagem e a leitura das frases contidas nas alternativas. Essa questão envolve o processo sintático e a estrutura gramatical de processamento sintático.

$\mathrm{Na}$ questão 11, a partir da leitura silenciosa das palavras contidas nas alternativas, o avaliado deve estabelecer a relação entre o par figura-escrita composta de palavras regulares e irregulares ortograficamente.

No item 12, é preciso atenção, pois o aplicador lê um texto enquanto a criança acompanha com a leitura silenciosa. Em seguida, o avaliado, a partir da compreensão textual, deve identificar o assunto do texto.

No quesito 13, o avaliado precisa inferir, a partir da leitura, a finalidade do texto, ou seja, por meio de habilidades metalinguísticas de nível fonológico, morfológico e sintático, deve atingir a habilidade cognitiva de inferência.

$\mathrm{Na}$ questão 14, solicita-se a compreensão textual. Nesse caso, o avaliado acompanha silenciosamente a leitura oral do texto, que contém palavras e imagem, feita pelo avaliador. Em seguida, o avaliador deve solicitar que o avaliado identifique a persona- 
gem principal do texto, o que exige memória, extração de significado pelo conteúdo semântico local (microestrutura) para chegar ao conteúdo semântico global (macroestrutura) que abarca as ideias essenciais do texto.

O item 15 exige compreensão textual do avaliado, que, a partir da leitura silenciosa do texto, deverá inferir informações sobre o texto por meio de suas micro e macroestruturas.

Nas questões 16 e 17, o avaliado deverá inferir, a partir da leitura, a finalidade do texto e compreendê-lo pelas suas características formais e também pelos conhecimentos prévios.

Nos quesitos de 18 a 20, a partir de leitura silenciosa realizada pelo avaliado ou da leitura oral feita pelo avaliador, o avaliado deve chegar à compreensão do texto pelas suas características formais e pelos conhecimentos prévios micro e macroestruturais do texto.

\section{Testes para medição das competências em leitura em um contexto escolar}

No Brasil, existem diversos testes para medição das competências em leitura: Capovilla e Capovilla (2006), Seabra e Capovilla (2010), Cuetos, Rodrigues e Rueno (2010), entre outros.

Para elucidar os testes de competência em leitura e escrita, serão apresentados os testes de avalição utilizados no contexto escolar por Mendes (2014). Foram selecionadas, por meio de amostragem aleatória, utilizando a divisão das escolas por zoneamento para a região insular da Secretaria Municipal de Educação de Santos, quatro UMEs do município de Santos sorteadas entre as 33 escolas que abrangem quatro áreas geográficas: Leste, Central, Noroeste e Morros, sendo uma para cada área.

Teste de Competência de Leitura de Palavras e Pseudopalavras (TCLPP) (SEABRA; CAPOVILLA, 2010), cujo objetivo é avaliar 
a competência de leitura silenciosa de palavras isoladas. É constituído de oito itens de treino e 70 itens de teste, e cada item é composto por um par que contém uma figura e um elemento escrito que pode ser uma palavra ou pseudopalavra. A criança deve circundar os itens corretos e assinalar um X nos itens incorretos. Nesse teste, há sete tipos de itens:

» Tipo 1: corretas regulares (CR), no qual há palavras ortográfica e semanticamente corretas e grafofonemicamente regulares a serem aceitas.

» Tipo 2: corretas irregulares (CI), no qual há palavras ortográfica e semanticamente corretas e grafofonemicamente irregulares a serem aceitas.

» Tipo 3: vizinhas semânticas (VS), no qual há palavras ortograficamente corretas, mas semanticamente incorretas a serem rejeitadas.

» Tipo 4: vizinhas visuais (VV), em que são apresentadas pseudopalavras ortograficamente incorretas, com trocas visuais, a serem rejeitadas.

» Tipo 5: vizinhas fonológicas (VF), no qual aparecem pseudopalavras ortograficamente incorretas, com trocas fonológicas, a serem rejeitadas.

" Tipo 6: pseudopalavras homófonas (PH), no qual são apresentadas pseudopalavras ortograficamente incorretas, embora homófonas a palavras semanticamente corretas, a serem rejeitadas.

» Tipo 7: pseudopalavras estranhas (PE), no qual estarão dispostas pseudopalavras ortograficamente incorretas e fonologicamente e visualmente estranhas a serem rejeitadas. A pontuação total para esse teste é 70 pontos.

Teste Contrastivo de Compreensão Auditiva e de Leitura (TCCAL) (CAPOVILLA; SEABRA, 2013), em que se avalia a habi- 
lidade de compreensão auditiva e de compreensão de leitura silenciosa. É composto por dois subtestes, e cada um possui seis itens de treino e 40 de teste, organizados em ordem crescente de dificuldade:

» Subteste de Compreensão de Sentenças Escritas (SCSE), que tem a finalidade de avaliar a compreensão de leitura. Nele, as frases estão escritas logo acima das figuras e devem ser lidas pela criança avaliada, que tem como tarefa escolher, entre as cinco figuras alternativas, aquela que corresponde à sentença lida.

» Subteste de Compreensão de Sentenças Faladas (SCSF), que mensura a habilidade de compreensão auditiva. O examinador pronuncia as frases em voz alta, visto que não estão escritas no teste. $\mathrm{O}$ avaliado deve escolher, entre as cinco figuras alternativas, aquela que corresponde à sentença ouvida.

A pontuação máxima em cada subteste é de 40 pontos e é interpretada separadamente.

Esses instrumentos foram aplicados nas próprias escolas do estudo mencionado, individualmente ou em grupo. A pesquisa foi realizada durante o período escolar regular em cinco dias diferentes, ao longo de cinco sessões, com duração aproximada de 20 a 30 minutos, no segundo semestre letivo de 2013.

Os resultados dos testes de avaliação de competência em leitura: Provinha Brasil - Leitura, TCLPP e TCCAL - subtestes SCSE e SCSF apresentaram os seguintes resultados de tendência central:

Para a Provinha Brasil - Leitura, as médias e desvio padrão obtidos são descritos na Tabela 5 .

É possível observar na Provinha Brasil - Leitura que as escolas Zona Central e Zona Morros apresentaram médias inferiores entre os sujeitos avaliados em relação às outras duas escolas. Nesse teste, 
TABELA 5 • MÉDIAS E DESVIO PADRÃO NA PROVINHA BRASIL - LEITURA

\begin{tabular}{|c|c|c|c|c|c|c|c|}
\hline \multicolumn{2}{|c|}{ ESCOLA } & \multirow{2}{*}{$\begin{array}{l}\mathbf{N} \\
34\end{array}$} & \multirow{2}{*}{$\begin{array}{c}\text { MÉDIA } \\
16,38\end{array}$} & \multirow{2}{*}{$\begin{array}{c}\text { DESVIO } \\
\text { PADRÃOO } \\
2,336\end{array}$} & \multirow{2}{*}{$\begin{array}{c}\text { MíNIMO } \\
11\end{array}$} & \multirow{2}{*}{$\begin{array}{c}\text { MÁXIMO } \\
20\end{array}$} & \multirow{2}{*}{$\begin{array}{c}\begin{array}{c}\text { PONTUAÇÃO } \\
\text { TOTAL }\end{array} \\
20\end{array}$} \\
\hline $\begin{array}{l}\text { PB - } \\
\text { Leitura }\end{array}$ & $\begin{array}{l}\text { 1- Zona } \\
\text { Leste }\end{array}$ & & & & & & \\
\hline & $\begin{array}{l}\text { 2- Zona } \\
\text { Central }\end{array}$ & 42 & 15,17 & 3,748 & 8 & 20 & 20 \\
\hline & $\begin{array}{l}\text { 3- Zona } \\
\text { Noroeste }\end{array}$ & 32 & 17,34 & 3,543 & 8 & 20 & 20 \\
\hline & $\begin{array}{l}\text { 4- Zona } \\
\text { Morros }\end{array}$ & 34 & 15,18 & 3,148 & 8 & 20 & 20 \\
\hline \multicolumn{2}{|c|}{ Total } & 142 & 15,95 & 3,355 & 8 & 20 & 20 \\
\hline
\end{tabular}

a escola Zona Leste despontou no acerto mínimo de questões. Entretanto, não apresentou a maior média de desempenho.

A média apresentada no desempenho das crianças das escolas denota um nível de leitura em que o aluno lê textos de, aproximadamente, oito a 10 linhas, na ordem direta, de estrutura sintática simples e de vocabulário que pertence ao repertório explorado na escola e tece inferências simples, conforme critério específico de desempenho (BRASIL, 2012d).

No Subteste de Compreensão de Sentença Escrita, a pontuação máxima é de 40 pontos. A escola Zona Leste apresentou pontuação acima da média nos resultados obtidos entre as escolas, enquanto a escola Zona Morros apresentou a menor pontuação média entre as escolas pesquisadas, conforme descrito na Tabela 6 .

Comparando a medida de tendência central (média) da pontuação bruta obtida nos testes PB - Leitura e SCSE aplicados por escola/zoneamento, é possível perceber que há uma variação entre a maior média obtida na PB - Leitura pela escola Zona Noroeste e a maior média obtida no SCSE pela escola Zona Leste.

Nos resultados obtidos no SCSF, a menor média obtida foi apresentada pela escola Zona Central, o que também ocorreu no SCSE, conforme a Tabela 7. 
TABELA 6 • MÉDIA E DESVIO PADRÃO - NO SUBTESTE COMPREENSÃO DE SENTENÇA ESCRITA

\begin{tabular}{|c|c|c|c|c|c|c|c|}
\hline \multicolumn{2}{|c|}{ ESCOLA } & \multirow{2}{*}{$\begin{array}{c}\mathbf{N} \\
34\end{array}$} & \multirow{2}{*}{$\begin{array}{l}\text { MÉDIA } \\
33,56\end{array}$} & \multirow{2}{*}{$\begin{array}{c}\begin{array}{c}\text { DESVIO } \\
\text { PADRÃO }\end{array} \\
8,897\end{array}$} & \multirow{2}{*}{ MÍNIMO } & \multirow{2}{*}{$\begin{array}{c}\text { MÁXIMO } \\
40\end{array}$} & \multirow{2}{*}{$\begin{array}{c}\text { PONTUAÇÃO } \\
\text { TOTAL }\end{array}$} \\
\hline SCSE & $\begin{array}{l}\text { 1- Zona } \\
\text { Leste }\end{array}$ & & & & & & \\
\hline & $\begin{array}{l}\text { 2-Zona } \\
\text { Central }\end{array}$ & 42 & 31,88 & 8,980 & 8 & 39 & 40 \\
\hline & $\begin{array}{l}\text { 3- Zona } \\
\text { Noroeste }\end{array}$ & 32 & 29,16 & 13,414 & 0 & 39 & 40 \\
\hline & $\begin{array}{l}\text { 4- Zona } \\
\text { Morros }\end{array}$ & 34 & 27,65 & 11,337 & 6 & 39 & 40 \\
\hline \multicolumn{2}{|c|}{ Total } & 142 & 30,65 & 10,807 & 0 & 40 & 40 \\
\hline
\end{tabular}

FONTE: ELABORADA PELOS AUTORES.

TABELA 7 • MÉDIA E DESVIO PADRÃO NO SUBTESTE DE COMPREENSÃO DE SENTENÇA FALADA

\begin{tabular}{|c|c|c|c|c|c|c|c|}
\hline \multicolumn{2}{|c|}{ ESCOLA } & \multirow{2}{*}{$\begin{array}{c}\mathbf{N} \\
34\end{array}$} & \multirow{2}{*}{$\begin{array}{l}\text { MÉDIA } \\
38,21\end{array}$} & \multirow{2}{*}{$\begin{array}{c}\text { DESVIO } \\
\text { PADRÃO0 } \\
1,871\end{array}$} & \multirow{2}{*}{$\begin{array}{c}\text { MÍNIMO } \\
32\end{array}$} & \multirow{2}{*}{$\begin{array}{c}\text { MÁXIMO } \\
40\end{array}$} & \multirow{2}{*}{$\begin{array}{c}\text { PONTUAÇÃO } \\
\text { TOTAL }\end{array}$} \\
\hline SCSF & $\begin{array}{l}\text { 1- Zona } \\
\text { Leste }\end{array}$ & & & & & & \\
\hline & $\begin{array}{l}\text { 2- Zona } \\
\text { Central }\end{array}$ & 42 & 36,60 & 3,045 & 26 & 40 & 40 \\
\hline & $\begin{array}{l}\text { 3- Zona } \\
\text { Noroeste }\end{array}$ & 32 & 37,44 & 2,602 & 29 & 40 & 40 \\
\hline & $\begin{array}{l}\text { 4- Zona } \\
\text { Morros }\end{array}$ & 34 & 37,71 & 1,404 & 34 & 40 & 40 \\
\hline \multicolumn{2}{|c|}{ Total } & 142 & 37,44 & 2,416 & 26 & 40 & 40 \\
\hline
\end{tabular}

FONTE: ELABORADA PELOS AUTORES.

No TCLPP, cuja pontuação máxima é 70, os sujeitos da escola Zona Central apresentaram 23 pontos, que é a menor pontuação, e não atingiram o máximo de acertos. A escola Zona Leste apresentou a maior média: 60,12. Nesse teste, a média foi de 56,68 entre os sujeitos avaliados e duas das escolas obtiveram média maior que a obtida pelo total de sujeitos avaliados nas quatro escolas, como pode ser verificado na Tabela 8 . 
TABELA 8 • MÉDIA E DESVIO PADRÃO NO TESTE COMPETÊNCIA EM LEITURA DE PALAVRAS E PSEUDOPALAVRAS

\begin{tabular}{|c|c|c|c|c|c|c|c|}
\hline \multicolumn{2}{|c|}{ ESCOLA } & \multirow{2}{*}{$\begin{array}{l}\mathbf{N} \\
34\end{array}$} & \multirow{2}{*}{$\begin{array}{c}\text { MÉDIA } \\
60,12\end{array}$} & \multirow{2}{*}{$\begin{array}{c}\begin{array}{c}\text { DESVIO } \\
\text { PADRÃO }\end{array} \\
6,494\end{array}$} & \multirow{2}{*}{$\begin{array}{c}\text { MÍNIMO } \\
48\end{array}$} & \multirow{2}{*}{$\begin{array}{c}\text { MÁXIMO } \\
70\end{array}$} & \multirow{2}{*}{$\begin{array}{c}\begin{array}{c}\text { PONTUAÇÃO } \\
\text { TOTAL }\end{array} \\
70\end{array}$} \\
\hline TCLPP & $\begin{array}{l}\text { 1- Zona } \\
\text { Leste }\end{array}$ & & & & & & \\
\hline & $\begin{array}{l}\text { 2- Zona } \\
\text { Central }\end{array}$ & 42 & 53,83 & 9,632 & 23 & 67 & 70 \\
\hline & $\begin{array}{l}\text { 3- Zona } \\
\text { Noroeste }\end{array}$ & 32 & 56,25 & 8,584 & 38 & 70 & 70 \\
\hline & $\begin{array}{l}\text { 4- Zona } \\
\text { Morros }\end{array}$ & 34 & 57,15 & 9,005 & 40 & 70 & 70 \\
\hline \multicolumn{2}{|c|}{ Total } & 142 & 56,68 & 8,797 & 23 & 70 & 70 \\
\hline
\end{tabular}

Após a verificação dos resultados dos testes de avaliação de competência em leitura, foi necessário observar se o zoneamento da escola avaliada exerce algum papel no desempenho dos escolares avaliados. Para tanto, foi utilizado o teste estatístico de análise de variância (Anova). Nesse teste, foi feita a comparação das médias entre os quatro grupos nos testes de avaliação de competência em Leitura (Provinha Brasil - Leitura, SCSE, SCSF, TCLPP), que mostrou que a diferença entre os grupos é significativa para a Provinha Brasil - Leitura (F (3,58); $p=0,01 ; p<0,05)$; SCSE (F $(3,12) ; p=$ $0,02 ; p<0,05)$ e TCLPP (F $(3,42) ; p=0,01 ; p<0,05)$. Na comparação dos grupos em pares, usando a análise post-hoc (Teste de Tukey), os grupos escola Zona Central e escola Zona Noroeste se diferenciaram entre si na Provinha Brasil; os grupos escola Zona Leste e escola Zona Morros não se diferenciaram entre si, e os grupos escola Zona Noroeste e escola Zona Morros também não se diferenciaram entre si em relação ao desempenho no SCSF e TCLPP.

Os grupos escola Zona Leste e escola Zona Central se diferenciaram entre si no Subteste de Compreensão de Sentença Falada (SCSF) e no Teste de Competência de Leitura de Palavras e Pseudopalavras (TCLPP). 
Verificou-se, por meio do teste de correlação de Pearson, que os resultados apresentam correlação positiva e significativa entre os testes de avaliação de competência em leitura. Assim, esse resultado encontra convergência com os estudos de Dias e Seabra (2013) e Seabra e Dias (2012) no que se refere à correlação de $r=0,52$, com $p<0,001$ entre o desempenho no SCSE do TCCAL e o reconhecimento de palavras avaliado pelo TCLPP. Isso também foi observado em relação ao SCSE e a Provinha Brasil - Leitura, com correlações significativas entre o desempenho nesse subteste e escore na Provinha Brasil - Leitura $(r=0,47, \operatorname{com} p<0,001)$. Os subtestes do TCCAL também se correlacionaram entre si $r=0,42, \operatorname{com} p<0,001$.

Para verificar se o efeito dos testes de leitura TCLPP, SCSE, SCSF e de itens de atividades realizados com os pais, assim como de atividades programadas, atividades entre pais e criança, presença de jornais e revistas em casa e tipos de livros em casa, extraídos do Questionário Informativo e Inventário Recursos do Ambiente Familiar - adaptado por Mendes (2014) -, exerce influência nos resultados da Provinha Brasil - Leitura, obtidos em contexto escolar, foi feita a análise de regressão linear, cujo resultado apontou que o $\mathrm{R}=0,655$ indica uma correlação moderada, conforme pesquisa realizada por Mendes (2014).

Essa análise possibilitou a identificação de um modelo que apresenta um coeficiente de determinação 0,429. Isso significa que $42,9 \%$ da variância no desempenho da Provinha Brasil - Leitura é explicado por informações socioambientais, testes de leitura aplicados e preditores de aprendizagem da leitura indicados no Inventário Recursos do Ambiente Familiar. O coeficiente de ajustamento à população foi de 0,339, ou seja, as constantes explicam até 33,9\% da variância na Provinha Brasil - Leitura. No que se refere ao erro padrão de estimativa, pode-se observar que a estimativa de variância é igual a 2,69.

De acordo com os valores de beta, a renda prediz $15 \%$, a compreensão auditiva, $31,1 \%$, e as diferentes escolas avaliadas 
por zoneamento, 6,5\%, no desempenho observado na Provinha Brasil - Leitura. Outro ponto a ser observado diz respeito à renda familiar, que prediz percentual baixo (15\%) no desempenho da Provinha Brasil - Leitura, divergindo dos resultados apontados por Bicalho e Alves (2010).

Assim, seria pertinente avaliar em que medida essa renda é utilizada em benefício da escolarização da criança e do desenvolvimento de práticas educativas que favoreçam a competência em leitura. Por outro lado, é importante ressaltar que 57,7\% das famílias das crianças enquadram-se na renda que varia de um a quatro salários mínimos, e 16,2\% têm renda familiar entre meio e um salário mínimo. Embora a informação sobre a quantidade de integrantes na família não tenha sido obtida, ainda assim aquelas que foram enquadradas entre meio e um salário mínimo apresentam rendas consideradas insuficientes para o mínimo investimento em instrução (IBGE, 2010).

Com relação às descrições das quatro escolas, mesmo estando localizadas em diferentes zonas geográficas, todas enquadram-se no mesmo padrão de infraestrutura física: possuem água, sanitário, energia, esgoto, cozinha, sala de diretoria, sala de professores, biblioteca, laboratório de informática, quadra e/ou local que permite convívio social e desenvolvimento motor, equipamentos de TV, DVD, computadores, impressora, copiadora e acesso à internet (NETO et al., 2013). No entanto, as diferentes escolas descritas no estudo predizem apenas 6,5\% no desempenho observado na Provinha Brasil - Leitura, o que nos leva a questionar em que medida todos esses recursos que a escola apresenta são utilizados em atividades que promovam a competência em leitura.

Os itens que tratam dos recursos do ambiente familiar (atividades realizadas, total de passeios, tipos de livros que pertencem à criança no ambiente familiar) predizem $24,7 \%$ no desempenho observado na Provinha Brasil - Leitura, o que corrobora, 
em parte, os estudos que tratam do suporte do ambiente familiar relacionados à competência em leitura (MARTURANO, 1999; TRIVELLATO-FERREIRA; MARTURANO, 2008; FERREIRA; BARRERA, 2010; SANTOS; GRAMINHA, 2005; ENRICONE; SALLES, 2011; PICCOLO et al., 2012).

Tendo em vista os dados obtidos no estudo de Mendes (2014), é possível observar que o desenvolvimento da competência leitora é pouco influenciado por informações socioambientais e recursos do ambiente familiar que não especifiquem a frequência, a quantidade de diálogos ocorridos entre os pais e as crianças, bem como o vocabulário dos pais.

A partir dos dados socioambientais (renda, escolaridade dos pais), variáveis de leitura (testes de leitura aplicados) e aspectos cognitivos que corroboram a competência em leitura (nomeação automática rápida de letras, números, cores e objetos) e recursos do ambiente familiar obtidos no estudo realizado por Mendes (2014), pode-se identificar tanto os fatores de risco quanto os de proteção, que contribuem para o desenvolvimento educacional, pessoal e social das crianças.

O nível de leitura das crianças do contexto escolar avaliado pelos testes de leitura e Provinha Brasil - Leitura é médio. Neles, é possível estabelecer a relação entre grafemas e fonemas, ler pequenos textos na ordem direta, com estrutura sintática simples, além de localizar informações evidentes em um pequeno texto e tecer inferências simples. Por meio do teste estatístico, foi verificado que não houve diferença nos resultados em relação à idade e ao gênero, e as quatro escolas também não diferiram nos resultados.

Os resultados do desempenho nas provas de leitura apresentaram pequenas nuances em suas médias.

A nomeação automática rápida de letras, números, cores e objetos apresentou correlação negativa significativa com os testes de leitura, o que indica que quanto maior o tempo gasto na nomeação, menor o domínio nas habilidades de leitura. Quanto aos 
dados socioambientais (renda e escolaridade dos pais) e testes de leitura, não houve correlação significativa.

As provas de leitura (Provinha Brasil - Leitura, Compreensão de Sentenças Escritas, Compreensão de Sentenças Faladas e Compreensão de Leitura de Palavras e Pseudopalavras) apresentaram correlação com o suporte do ambiente familiar, preditor da competência de leitura: brinquedos.

$\mathrm{Na}$ análise de regressão, 42,9\% da variância no desempenho na Provinha Brasil - Leitura é explicada pelos dados socioambientais, testes de competência em leitura e recursos do ambiente familiar que podem ser considerados preditores da competência em leitura, sendo o restante possivelmente explicado por características individuais da criança.

Considerando os resultados apresentados, é possível perceber a complexidade que envolve o estudo do desempenho e competência acadêmica e em leitura.

Sugere-se, a partir desses resultados, que o desenvolvimento de habilidades para a compreensão de sentenças escritas, nomeação automática rápida de objetos, letras, números e cores, leitura de palavras e pseudopalavras seja promovido no contexto escolar. Em estudos e experiências futuros, será necessário detalhar ou detectar, em cada aspecto do contexto psicossocioambiental avaliado, a oferta de experiências com linguagem escrita, por meio da leitura compartilhada de histórias, livros, brinquedos didáticos para o desenvolvimento de linguagem etc.

Com relação à competência em leitura e suportes do contexto familiar para o bom desempenho escolar e em leitura, como a participação da família nos processos escolares para estimular um ambiente de aprendizagem profícuo, os resultados, em que pese a divergência em fatores como nível socioeconômico e escolaridade dos pais e a convergência para fatores de suporte familiar, como a presença de brinquedos, livros, passeios realizados com a criança, sugerem a necessidade da implantação de uma 
política pública que valorize a participação familiar na escola com maior contundência do que a existente. Além disso, demandam a implantação de nova modelagem do processo de alfabetização pautada nos pressupostos da abordagem cognitiva e achados da neurociência.

As políticas públicas poderão estar pautadas na valorização da participação familiar no contexto escolar com foco na orientação dos pais em relação às práticas mais bem-sucedidas para ajudar os filhos a desenvolver suas habilidades linguísticas.

Essas práticas deverão envolver a leitura compartilhada de histórias, o estabelecimento de hábitos de diálogos rotineiros entre as crianças e os pais sobre histórias ocorridas no dia a dia, jogos com a utilização de letras e sentenças, jogos de discriminação auditiva, familiarização com livros e outros materiais impressos. Temos como exemplo o que fizeram o governo americano, por meio do Departamento de Educação no programa No child left behind, e o governo da Nova Zelândia, com o programa intitulado Home-school partnerships: literacy programme, quando implementaram políticas públicas de educação que envolviam a participação dos pais no desenvolvimento dessas atividades. 


\section{Referências}

AARON, P. G. et al. Diagnosis and treatment of reading disabilities based on the component model of reading: an alternative to the discrepancy model of LD. Journal of Learning Disabilities, v. 41, n. 1, p. 67-84, Jan./Feb. 2008.

ALÉGRIA, J.; LEYBAERT, J.; MOUSTY, P. Aquisição da leitura e distúrbios associados: avaliação, tratamento e teoria. In: GREGÓIRE, J.; PIÈRART, B. Avaliação dos problemas de leitura: os novos modelos teóricos e suas implicações diagnósticas. Porto Alegre: Artes Médicas, 1997.

ASSOCIAÇÃO BRASILEIRA DE EMPRESAS DE PESQUISA - Abep. Critério de Classificação Econômica Brasil. 2012.

BANDEIRA, M. et al. Competência acadêmica de crianças do ensino fundamental: características sociodemográficas e relação com habilidades sociais. Interação em Psicologia, v. 10, n. 1, p. 53-62, 2006 a.

. Habilidades sociais e variáveis sociodemográficas em estudantes do ensino fundamental. Psicologia em Estudo, Maringá, v. 11, n. 3, p. 541-549, set./ dez. 2006b.

BARBANTE, E. C.; AMARO JR., E.; COSTA, J. C. As bases neurobiológicas da aprendizagem da leitura. In: ARAÚJO, A. P. de. (Coord.). Aprendizagem infantil: uma abordagem da neurociência, economia e psicologia cognitiva. Rio de Janeiro: Academia Brasileira de Ciências, 2011.

BARREIRA, S. D.; MALUF, M. R. Consciência metalinguística e alfabetização: um estudo com crianças da primeira série do ensino fundamental. Psicologia: reflexão e crítica, Porto Alegre, v. 16, n. 3, p. 491-502, 2003.

BICALHO, L. G. R.; ALVES, L. M. A nomeação seriada rápida em escolares com e sem queixas de problemas de aprendizagem em escola pública e particular. Revista Cefac, São Paulo, v. 12, n. 4, p. 608-616, jul./ago. 2010. 
BOWERS, P. G. Tracing symbol naming speed's unique contributions to reading disabilities over time. Reading and Writing: an interdisciplinary journal, v. 7, p. $189-216,1995$

BRAIBANT, J.-M. A decodificação e a compreensão: dois componentes essenciais da leitura no $2^{ }$ano primário. In: GREGÓIRE, J.; PIÈRART, B. Avaliação dos problemas de leitura: os novos modelos teóricos e suas implicações diagnósticas. Porto Alegre: Artes Médicas, 1997.

BRASIL. Ministério da Educação. Secretaria de Educação Básica. O ensino fundamental de nove anos: orientações gerais. Brasília: MEC/SEB, 2004.

. Ministério da Educação. Portaria Normativa no 10 , de 24 de abril de 2007. Institui a Avaliação de Alfabetização Provinha Brasil. Diário Oficial, 26 de abril de 2007.

. Ministério da Educação. Instituto Nacional de Estudos e Pesquisas Educacionais Anísio Teixeira. Provinha Brasil: passo a passo. Brasília: Inep/MEC, 2009.

Ministério da Educação. Instituto Nacional de Estudos e Pesquisas Educacionais Anísio Teixeira. Escala de desempenho de Língua Portuguesa Ensino Fundamental. 2011. Disponível em: <http://download.inep.gov.br/educacao_ basica/prova_brasil_saeb/escala/2011/escala_desempenho_portugues_fundamental.pdf>. Acesso em: 10 maio 2015.

. Ministério da Educação. Instituto Nacional de Estudos e Pesquisas Educacionais Anísio Teixeira. Provinha Brasil: Caderno do aluno - Leitura - Teste 2. Brasília: Inep/MEC, 2012a.

Ministério da Educação. Instituto Nacional de Estudos e Pesquisas Educacionais Anísio Teixeira. Provinha Brasil: Guia de Aplicação - Leitura - Teste 2. Brasília: Inep/MEC, 2012 b.

- Ministério da Educação. Secretaria de Educação Básica. Portaria no 867. Pacto Nacional pela Alfabetização na Idade Certa. Brasília: MEC, 2012c.

. Ministério da Educação. Instituto Nacional de Estudos e Pesquisas Educacionais Anísio Teixeira. Provinha Brasil: Guia de Correção e Interpretação de Resultados - Leitura - Teste 2. Brasília: Inep/MEC, 2012d.

. Ministério da Educação. Secretaria de Educação Básica. Diretrizes Curriculares Nacionais Gerais da Educação Básica. Brasília: MEC/SEB/Dicei, 2013. BROOKING, K.; ROBERTS, J. Evaluation of the home-school partnership: literacy programme. New Zealand Council for Educational Research, 2007.

CAMPBELL, C. How to involve hard-to-reach parents: encouraging meaningful parental involvement with schools [full report]. National College for School 
Leadership, Autumn 2011. Disponível em: <http://dera.ioe.ac.uk/12136/1/dow nload\%3Fid\%3D156367\%26filename\%3Dhow-to-involve-hard-to-reach-parents-full-report.pdf>. Acesso em: 29 jun. 2015.

CAPELlinI, S. A.; TONELOTTO, S. M. F.; CIASCA, S. M. Medidas de desempenho escolar: avaliação formal e opinião de professores. Revista Estudos de Psicologia, Campinas, v. 21, n. 2, p. 79-90, maio/ago. 2004.

CAPELLINI, S. A. et al. Desempenho de escolares bons leitores, com dislexia e com transtorno de déficit de atenção e hiperatividade em nomeação automática rápida. Revista da Sociedade Brasileira de Fonoandiologia, São Paulo, v. 12, n. 2, p. 114-119, abr./jun. 2007.

CAPELLINI, S. A.; LANZA, S. C. Desempenho de escolares em consciência fonológica, nomeação rápida, leitura e escrita. Pró-Fono Revista de Atualização Cientifica, Barueri, v. 22, n. 3, p. 239-244, jul./set. 2010.

CAPOVILLA, A. G. S.; CAPOVILLA, F. C. Problemas de leitura e escrita: como identificar, prevenir e remediar numa abordagem fônica. São Paulo: Memnon, 2000 .

. Alfabetização: método fônico. São Paulo: Memnon Edições Científicas, 2002.

CAPOVILlA, A. G. S.; CAPOVILlA, F. C.; SOARES, J. V. T. Consciência sintática no ensino fundamental: correlações com consciência fonológica, vocabulário, leitura e escrita. Psico-USF, v. 9, n. 1, p. 39-47, jan./jun. 2004.

CAPOVILLA, A. G. S. et al. Teste de nomeação de figuras: evidências de precisão e validade em crianças pré-escolares. Psico. Pesq., v. 1, n. 2, p. 23-31, 2007.

CAPOVIlla, F. C.; CAPOVIllA, A. G. S. Prova de Consciência Sintática (PCS): normatizada e validada: para avaliar a habilidade metassintática de escolares de $1^{\underline{a}}$ a $4^{\underline{a}}$ séries do Ensino Fundamental. São Paulo: Memnon, 2006.

CAPOVILLA, F. C.; SEABRA, A. G. Teste Contrastivo de Compreensão Auditiva e de Leitura. In: SEABRA, A. G.; DIAS, N. M.; CAPOVILLA, F. C. (Org.). Avaliação neuropsicológica cognitiva: leitura, escrita e aritmética. São Paulo: Memnon, 2013. v. 3.

CARDOSO-MARTINS, C.; PENNINGTON, B. F. Qual é a contribuição da nomeação seriada rápida para a habilidade de leitura e escrita? Evidência de crianças e adolescentes com e sem dificuldades de leitura. Psicologia: reflexão e crítica, Porto Alegre, v. 14, n. 2, p. 387-397, 2001.

CORNWALL, A. The relationship of phonological awareness, rapid naming, and verbal memory to severe Reading and spelling disability. Journal of Learning Disabilities, v. 25, n. 8, p. 532-538, out. 1992. 
CUETOS, F.; RODRIGUES, B.; RUENO, E. Prolec: provas de avaliação dos processos de leitura. Adaptação para o português: OLIVEIRA, A. M.; CAPELLINI, S. A. Desempenho de escolares na adaptação brasileira da avaliação dos processos de leitura. Pró-Fono R. Atual. Cient., Barueri, v. 22, n. 4, p. 555-560, out./dez. 2010.

DIAS, N. M.; SEABRA, A. G. Leitura, escrita e aritmética: avaliação neuropsicológica cognitiva. São Paulo: Memnon, 2013.

DOURADO, L. F. Fracasso escolar no Brasil: políticas, programas e estratégias de prevenção ao fracasso escolar. In: BRASIL. Ministério da Educação. Elaboração de políticas e estratégias para a prevenção do fracasso escolar. Brasília: MEC, 2005.

ELLIS, A.; YOUNG, A. W. Human cognitive neuropsychology. London: Lawrence Erlbaum, 1988.

ENRICONE, J. R. B.; SALLES, J. F. de. Relação entre variáveis psicossociais familiares e desempenho em leitura/escrita em crianças. Psicol. Esc. Educ., Maringá, v. 15, n. 2, p. 199-210, dez. 2011.

FERREIRA, S. H. A.; BARRERA, S. D. Ambiente familiar e aprendizagem escolar em alunos da educação infantil. Psico, Porto Alegre, v. 41, n. 4, p. 462-472, out./dez. 2010.

GERMANO, G. D.; PINHEIRO, F. H.; CUNHA, V. L. O. Avaliação e intervenção nas habilidades metalinguísticas. In: CAPELLINI, A. S.; GERMANO, G. D.; CUNHA, V. L. O. Transtornos de aprendizagem e transtornos de atenção: da avaliação à intervenção. São José dos Campos: Pulso Editorial, 2010. p. 35-48.

GONTIJO, C. M. M. Avaliação da alfabetização: Provinha Brasil. Educ. Pesqui., São Paulo, v. 38, n. 3, p. 603-622, set. 2012.

GUIMARÃES, S. R. K. O aperfeiçoamento da concepção alfabética de escrita: relação entre consciência fonológica e representações ortográficas. In: MALUF, M. R. Metalinguagem e aquisição da escrita. São Paulo: Casa do Psicólogo, 2003. p. 149-184.

INSTITUTO BRASILEIRO DE GEOGRAFIA E ESTATÍSTICA. Pesquisa Nacional por amostra de domicílios. Rio de Janeiro: IBGE, 2005.

. Pesquisa de orçamentos familiares (2008-2009). Despesas, rendimentos e condições de vida. Rio de Janeiro: IBGE, 2010.

JOSHI, R. M.; AARON, P. G. The component model of reading simple view of reading made a little more complex. Reading Psychology, v. 21, n. 2, p. 85-97, 2000. 
KEOGH, B. K.; WEISNER, T. An ecocultural perspective on risk and protective factors in children's development: implications for learning disabilities. Learning Disabilities Research \& Practice, v. 8, n. 1, p. 3-10, Winter 1993.

KINTSCH, W.; VAN DIJK, T. A. Toward a model of text comprehension and production. Psychological Review, v. 85, n. 5, p. 363-394, Sept. 1978.

MARTURANO, E. M. Recursos no ambiente familiar e dificuldades de aprendizagem na escola. Psicologia: teoria e pesquisa, v. 15, n. 2, p. 135-142, maio/ago. 1999.

. O inventário de recursos do ambiente familiar. Psicologia: reflexão e crítica, Porto Alegre, v. 19, n. 3, p. 498-506, 2006.

MATTOSO CÂMARA, J. História e estrutura da língua portuguesa. Rio de Janeiro: Padrão Livraria Editora, 1985.

MEDEIROS, P. C. et al. A autoeficácia e os aspectos comportamentais de crianças com dificuldades de aprendizagem. Psicologia: reflexão e crítica, Porto Alegre, v. 13, n. 3, p. 327-336, 2000.

. O senso de autoeficácia e o comportamento orientado para aprendizagem em crianças com queixa de dificuldades de aprendizagem. Estudos de Psicologia, Natal, v. 8, n. 1, p. 93-105, jan./abr. 2003.

MENDES, E. C. C. S. Provinha Brasil - Instrumento Avaliativo de Leitura: análise à luz da abordagem cognitiva de leitura e seus resultados. In: CONGRESSO INTERNACIONAL GALEGO-PORTUGUÊS DE PSICOPEDAGOGIA, 12. 2013, Braga. Atas... Braga: Universidade do Minho, 2013. p. 4.192-4.206.

. Relações entre variáveis psicossociambientais e competência em leitura de crianças do $3^{\circ}$ ano do ensino fundamental. 2014. Tese (Doutorado em Distúrbios do Desenvolvimento)-Universidade Presbiteriana Mackenzie, São Paulo, 2014.

MONTEIRO, R. M.; SANTOS, A. A. A. Recursos familiares e desempenho de crianças em compreensão de leitura. Psico, Porto Alegre, v. 44, n. 2, p. 273-279, abr./jun. 2013.

MORAIS, J. A arte de ler. São Paulo: Editora Unesp, 1996.

MORAIS, J. et al. Literacy training and speech segmentation. Cognition, v. 34, p. 45-64, 1986.

MURILLO, J. F.; MARTINEZ-GARRIDO, C. Las condiciones ambientales en las aulas de Primaria en Iberoamérica y su relación con el desempeño académico. Archivos Analíticos de Políticas Educativas, Tempe, v. 20, n. 18, p. 1-19, 2012.

NASCIMENTO, P. A. M. Fatores associados ao desempenho escolar: resultados de um modelo multinível de valor adicionado. Est. Aval. Educ., São Paulo, v. 23, n. 51, p. 16-39, jan./abr. 2012. 
NETO, J. J. S. et al. Uma escala para medir infraestrutura escolar. Est. Aval. Educ., São Paulo, v. 24, n. 54, p. 78-99, jan./abr. 2013.

NIKAEDO, C. C.; KURIYAMA, C. T.; MACEDO, E. C. de. Avaliação longitudinal de leitura e escrita com testes de diferentes pressupostos teóricos. Revista de Psicologia da Vetor Editora, v. 8, n. 2, p. 185-193, jul./dez. 2007.

OLIVEIRA, J. B. A. Avaliação em alfabetização. Ensaio: avaliação das políticas públicas, Rio de Janeiro, v. 13, n. 48, p. 375-382, jul./set. 2005.

PAPALIA, D. E.; OLDS, S. W.; FELDMAN, R. D. Desenvolvimento humano. Porto Alegre: Artmed, 2009.

PICCOLO, L. et al. Variáveis psicossociais e desempenho em leitura de crianças de baixo nível socioeconômico. Psicologia: teoria e pesquisa, Brasília, v. 28, n. 4, p. 389-398, out./dez. 2012.

PIRES, T. de O. Fatores psicossociais relacionados ao transtorno de déficit de atenção/hiperatividade em escolares do Município de São Gonçalo. 2011. Dissertação (Mestrado em Epidemiologia em Saúde Pública)-Escola Nacional de Saúde Pública Sergio Arouca, Rio de Janeiro, 2011.

PROGRAMA INTERNACIONAL DE AVALIAÇÃO DE ALUNOS - PISA 2009. Disponível em: <http://www.inep.gov.br/imprensa/noticias/internacional/ news10_01.htm>. Acesso em: 10 maio 2015.

ROSAL, A. G. C. Contribuições da consciência fonológica e nomeação seriada rápida para a aprendizagem inicial da escrita. 2014. Dissertação (Mestrado em Saúde da Comunicação Humana)-Universidade Federal de Pernambuco, Recife, 2014.

SALLES, J. F.; PARENTE, M. A. M. P. Processos cognitivos na leitura de palavras em crianças: relações com compreensão e tempo de leitura. Psicologia: reflexão e crítica, Porto Alegre, v. 15, n. 2, p. 321-331, 2002 a.

Relação entre os processos cognitivos envolvidos na leitura de palavras e habilidades de consciência fonológica em escolares. Pró-fono Revista de Atualização Científica, v. 14, n. 2, p. 175-186, maio/ago. 2002 b.

Avaliação da leitura e escrita de palavras em crianças de $2^{\underline{a}}$ série: abordagem neuropsicológica cognitiva. Psicologia: reflexão e crítica, Porto Alegre, v. 20, n. 2, p. 220-228, 2007.

SANTOS, M. T. M. Vocabulário, consciência fonológica e nomeação rápida: contribuições para a ortografia e elaboração escrita. 2007. Tese (Doutorado em Semiótica e Linguística Geral)-Universidade de São Paulo, São Paulo, 2007.

SANTOS, E.; ANDERLE, S. T. dos S.; ROSA NETO, F. O que é ler e escrever? In: ROSA NETO, F.; SANTOS, E. R. dos; TORO, J. Manual de desempenho 
escolar: análise de leitura e escrita: séries iniciais do ensino fundamental. Palhoça: Unisul, 2010.

SANTOS, P. L.; GRAMINHA, S. S. V. Estudo comparativo das características do ambiente familiar de crianças com alto e baixo rendimento escolar. Cadernos de Psicologia e Educação (Paidéia), Ribeirão Preto, v. 15, n. 31, p. 217-226, maio/ago. 2005.

SANTOS. Relatório Santos: perfil dos objetivos de desenvolvimento do milênio em Santos - jun. 2009. Disponível em: <http://agendapublica.org.br/wp-content/ uploads/2014/03/relatorio_santos.pdf>. Acesso em: 10 maio 2015.

SÃO PAULO. Fundação Sistema Estadual de Análise de Dados. Censo 2010. Informações dos Municípios Paulistas. Disponível em: <http://www.seade.gov. br/banco-de-dados>. Acesso em: 10 maio 2015.

. Secretaria da Educação do Estado de São Paulo. Fundação para o Desenvolvimento da Educação. Relatório de Estudos do Saresp 2011. São Paulo, 2012. SEABRA, A. G.; CAPOVILlA, F. C. Teste de Competência de Leitura de Palavras e Pseudopalavras. São Paulo: Memnon, 2010.

SEABRA, A. G.; DIAS, N. M. Reconhecimento de palavras e compreensão de leitura: dissociação e habilidades linguístico-mnemônicas preditoras. Revista Neuropsicologia Latinoamericana, v. 4. n. 1, p. 45-56, 2012.

SILVA, C. da; FUSCO, N.; CUNHA, V. L. O. Avaliação e intervenção na leitura. In: CAPELLINI, S. A.; GERMANO, G. D.; CUNHA, V. L. O. (Org.). Transtornos de aprendizagem e transtornos de atenção: da avaliação à intervenção. São José dos Campos: Pulso Editorial, 2010.

SILVA, C. da; CAPELLINI, S. A. Correlação entre tempo, erro, velocidade e compreensão de leitura em escolares com distúrbio de aprendizagem. Revista Sociedade Brasileira de Fonoandiologia, v. 16, n. 4, p. 412-416, dez. 2011.

SILVA, C. da et al. Nomeação rápida, leitura e compreensão em escolares com dificuldades de aprendizagem. Jornal da Sociedade Brasileira de Fonoaudiologia, São Paulo, v. 24, n. 4, p. 355-360, 2012.

SILVA, P. B.; MACEDO, E. C. Evidências de validade do teste de nomeação automática rápida para amostra de crianças brasileiras. No prelo.

SOARES, J. F.; ANDRADE, R. J. de. Nível socioeconômico, qualidade e eqüidade das escolas de Belo Horizonte. Ensaio: Avaliação e Políticas Públicas em Educação, Rio de Janeiro, v. 14, n. 50, p. 107-126, jan./mar. 2006.

SOARES, J. F.; ALVES, M. T. G. Escolas de ensino fundamental: contextualização dos resultados. Revista Retratos da Escola, Brasília, v. 7, n. 12, p. 145-158, jan./jun. 2013. 
SOARES, J. F.; COLLARES, A. C. M. Recursos familiares e o desempenho cognitivo dos alunos do ensino básico brasileiro. Dados - Revista de Ciências Sociais, Rio de Janeiro, v. 49, n. 3, p. 615-650, 2006.

SOARES, M. Em busca da qualidade em alfabetização: em busca... de quê? In: Alfabetização e letramento. 6. ed. São Paulo: Contexto, 2011.

SOUSA, S. Z.; ARCAS, P. H. Implicações da avaliação em larga escala no currículo: revelações de escolas estaduais de São Paulo. Educação: teoria e prática, Rio Claro, v. 20, n. 35, p. 181-199, jul./dez. 2010.

STEENSEL, R. van. Relations between socio-cultural factors, the home literacy environment and children's literacy development in the first years of primary education. Journal of Research in Reading, v. 29, n. 4, p. 367-382, Nov. 2006.

SZYMANSKI, H. A relação famílialescola: desafios e perspectivas. Brasília: Líber Libro, 2007.

TRIVELLATO-FERREIRA, M. da C.; MARTURANO, E. M. Recursos da criança, da família e da escola predizem competência na transição da $1^{\underline{a}}$ série. Revista Interamericana de Psicologia, Porto Alegre, v. 42, n. 3, p. 549-558, dez. 2008.

WEISS, H. B. et al. Reframing family involvement in education: supporting families to support educational equity. Equity matters: research review, Nova York, n. 5, Dec. 2009.

ZHANG, Y. et al. Phonological skills and vocabulary knowledge mediate socioeconomic status effects in predicting reading outcomes for Chinese children. American Psychological Association, v. 49, n. 4, p. 665-671, Apr. 2013. 


\section{Índice}

A

Abordagem
$\quad$ cognitiva $14,17,60,61,73$

ecocultural de desenvolvimento

23

Alfabetização 13, 14, 16, 21, 32, 33, $45,54,55,57,58,73$

Ambiente

cultural 22

doméstico 22, 34

escolar 12, 21, 26, 46

familiar 9, 14, 21, 27, 31, 32, 34$37,70-72$

Aprendizagem

da leitura 11, 13, 15, 19, 21, 30, $34,35,40,69$

escolar 23, 31, 33

Aquisição

da leitura 10, 11, 12, 15

da linguagem escrita 16, 17, 39

C

Capovilla, Fernando 12, 14, 16-18, $21,22,39,63,64$

Compreensão

auditiva 9, 65, 69

de leitura 32-35, 62, 65

de texto $12,19,20,35,63$

Consciência

fonológica 16, 17, 40

sintática 16, 17

Contexto

escolar 46, 63, 69, 71-73

familiar 24, 27, 31, 38, 72

D

Desempenho

em leitura 11, 12, 25-27, 34, 39, 47

escolar 9, 11, 31, 32, 72

Dificuldade

de aprendizagem 35, 40

de leitura 25,26

E

Estímulos visuais 19, 38

Estratégia de leitura

fonológica 18

lexical 18

logográfica 18

Estrutura

fonológica 18

sintática 58, 66 
F-G

Fatores

de risco 23, 31, 71

neurobiológicos 25

psicossociais $25,26,31,33$

Gênero 11, 22, 32, 48, 56, 58, 71

I

Índice de Desenvolvimento da

Educação Básica (Ideb) 25, 47

Instituto Brasileiro de Geografia e

Estatística (IBGE) 24, 70

Instituto Nacional de Estudos e

Pesquisas Educacionais Anísio

Teixeira (Inep) 11, 47, 53

\section{$\mathrm{K}-\mathrm{M}$}

Keogh, Barbara 23

Letramento 25, 54, 55, 61

Marturano, Edna 14, 22, 24, 31, 34, $35,37,40,71$

Ministério da Educação (MEC) 11, $13,33,45,47,54$

$\mathrm{N}$

Neurociência 73

Nomeação automática rápida

(NAR) 19, 38, 40, 42, 43, 71, 72

\section{P-R}

Processamento

da informação 17

fonológico 17, 25 linguístico 16

sintático 62

Recursos do ambiente familiar

(RAF) 27, 32, 34-36, 70-72

Rota

fonológica 18, 61

lexical 17, 18

$\mathrm{S}$

Salles, Jerusa 14, 17, 18, 22, 24, 25, 37,40

Seabra, Alessandra Gotuzo 22, 40,

$63,64,69,71$

T

Teste Contrastivo de Compreensão Auditiva e de Leitura (TCCAL) $65,65,69$

Teste de Competência de Leitura de Palavras e Pseudopalavras

(TCLPP) 36, 37, 63, 65, 68, 69

\section{V-W}

Variáveis

ambientais 22

cognitivas 22

psicológicas 22

psicossociais 26

psicossocioambientais $27,30,34$

socioambientais 30,34

Weisner, Thomas 23 